\title{
Nieuwe Getuigenissen over Stormvloedschade in Zeeuws-Vlaanderen, in de jaren 1375 tot 1412
}

\author{
Hans D. MEYER ${ }^{1}$
}

1

Daar de overlevering betreffende de katastrofale stormvloeden van 1375 en 1404, alsook over de watersnood van de volgende jaren, erg pover blijkt, is ieder tot nog toe niet bekend getuigenis erover van zeer groot belang. Wat nu volgt, zijn verklaringen van tijdgenoten, die veelal zelfs ooggetuigen van de gebeurtenissen zijn geweest, doch die niet zozeer de katastrofe zelf beschrijven dan wel de veroorzaakte schade in het algemeen. Zonder in te gaan op de diskussie of de Anonymus van het Chronicon comitum Flandrensium, die erover heeft geschreven, ook inderdaad een tijdgenoot is geweest, blijven de hiema behandelde berichten de enige uit die tijd, in de enge betekenis van het woord ${ }^{2}$.

De aanleiding tot de ondervraging van deze getuigen en tot de optekening van hun verklaringen, kan uit de inleiding van de hier besproken tekst worden afgeleid. Deze aanleiding was een bijzondere kerkelijke belasting die de Gentse Sint-Baafsabdij moest betalen en die "in regno Francie et dalphinatu Viennensi" in naam van de paus en de apostolische kamer werd geheven. De som evenaarde een tiende van een jaar en werd in twee afbetalingen gestort. Kapelaan Guillelmus de Quercu (Willem Van Eyck) inde, als tiendeontvanger van het bisdom Doornik, de gevorderde bedragen. Het is dan ook tot hem, dat Sint-Baafs zich met een uitvoerige brief richtte

1 Gewezen gewoon hoogleraar aan de R.W.T.H. (Rhein.-Westf. Techn. Hochschule, Aachen). Voor de vertaling uit het Duits gaat onze hartelijke dank naar dr. J. De Ridder (Gent). Voor zijn moeite en de talrijke waardevolle suggesties ben ik ook prof. dr. A. Verhulst (Universiteit Gent) ten zeerste schatplichtig.

2 Rijksarchief Gent, Fonds St.-Baafs R816/1. De hierbijgevoegde jongere kopie, (R816/2), is waardeloos voor het vaststellen van de tekst. Inventarisnummers zonder andere specificaties verwijzen steeds naar: RAGent, St.-Baafs.

Afgekorte titels:

Gottschalk HG 1 resp. HG2 =

Gottschalk, M.K.E., Historische geografie van Westelijk ZeeuwsVlaanderen, Bd. 1 Assen, 1955; Bd. 2 Assen 1958.

Verhulst, Grondbezit = Brussel 1958.

Verhulst, A., De Sint-Baafsabdij te Gent en haar grondbezit (7e-14e eeuw),

Gottschalk, Vier Ambachten =

Gottschalk, M.K.E., De Vier Ambachten en het Land van Saaftinge in de Middeleeuwen, Assen 1984. 


\section{H. D. MEYER}

om van deze extra-taks verschoond te worden.

Het verzoek verwees daarvoor naar het enorme verlies van inkomsten, dat de abdij in de afgelopen veertig jaar had geleden, en wel door twee oorzaken: waterschade door de overstromingen sedert 1375, en in die zelfde tijd oorlogsschade door Engels-Frans-Vlaamse vijandelijkheden. De brief was uitvoerig en in artikels (articuli) ingedeeld. Er werd echter bewust niet ingegaan op bijzonderheden van plaats, geld of uitgestrektheid van grondbezit. De bewijsvoering was er in hoofdzaak op gericht aan te tonen dat Sint-Baafs in de diverse gebieden ruim de helft van al haar bezittingen en inkomsten verloren had ${ }^{3}$.

Daar de tiendontvanger van het bisdom echter de biezonderheden van de klacht wilde nagaan, stelde hij, op 30 november 1411, twee ook uit andere rechtzaken betreffende Sint-Baafs bekende vertrouwenslieden aan om de nodige getuigen te onderhoren. Het waren met name proost Livinus Blekere uit Gent en kanunnik Johannes Nemegheer uit Mechelen ${ }^{4}$. De getuigen werden gehoord van 5 tot 12 januari 1412. Elk punt apart kwam hierbij ter sprake, en wel zo dat telkens wordt verwezen naar het betreffende artikel en het verzoekschrift van Sint- Baafs. Zo kwamen na een groep getuigen die over algemeenheden was verhoord, meerdere groepen die bepaaldelijk over één enkele streek of over één speciaal goederencomplex verklaringen aflegden. Overigens zijn hun respektievelijke namen, hoewel vertaald of verlatijnst, gemakkelijk in hun Vlaamse oorspronkelijke versie te herkennen.

De hele zaak werd op 16 augustus 1412 beslecht door Guillelmus de Quercu, die besliste de bijdrage van Sint-Baafs te reduceren tot $112 \mathrm{lb}$. gr.; som waarvoor hij terstond kwijting gaf. Hieruit blijkt duidelijk, dat de getuigen indruk hadden gemaakt ook al had men niet de algehele kwijtschelding verkregen - die men wellicht zelfs niet eens verwacht had.

We kunnen trouwens de reduktie van het bedrag niet precies beoordelen, gezien we de eigenlijke som die verschuldigd was niet eens kennen. We kunnen dan ook niet juist weten of de abdij tenslotte slechts de helft heeft moeten betalen.

In wat nu volgt zullen wij het dokument met de verklaringen van de getuigen niet volledig bespreken, doch ons uitsluitend beperken tot het probleem van de vloedschade. We gaan dus aan de oorlogsdaden voorbij,

3 Hierover de niet nader te dateren tekst K 10517 uit de tijd van abt Georges Van Der Zickelen (1405-1418), waarin o.a.de aanvraag wordt gedaan tot vermindering van de tienden tot de helft. Met verwijzing naar de vloedschade, heeft de abdij het daar over het totaal verlies van een deel van haar bezittingen, en raamt hetgeen overbleef, zonder in details te treden, op nauwelijks de helft ("vix medie(ta)tem"). Over de abt in kwestie: Berings, G. en Lebbe, Ch., Abbaye de SaintBavon à Gand, in: Monasticon Belge. Tome VII province de la Flandre Orientale, premier volume 57-58.

$4 \quad$ Vgl. ol 008 (1404.11.15); 01689 (1418.09.25). 
evenals aan de kwestie van de lijfrenten - op één uitzondering na -, hoewel deze als betaalmiddel bij de regeling van schadevergoedingen uiteraard nauw betrokken waren bij de behandeling van de schade veroorzaakt door stormvloeden. Daar het verder eveneens verkieslijk is de respektieve getuigenissen in te delen naar de streek waarop ze betrekking hadden, in plaats van naar hun volgorde in de protokollen, willen wij de getuigen eerst elk afzonderlijk karakterizeren en beschrijven, voor zover dit nodig is voor de beoordeling van hun respektieve uitspraken. Het ligt hierbij voor de hand, dat deze beschrijvingen op zichzelf al van enig belang kunnen zijn voor de prosopografie van personen uit de omgeving van de Sint-Baafsabdij. Bovendien werden hierin, zonder volledigheid na te streven, vele gegevens verwerkt, die aan de hand van de nog lang niet volledig doorvorste archivalia van Sint-Baafs kunnen aangevuld worden.

Van de 26 personen die aan het woord komen, zijn er slechts 19 die ons interesseren, gezien de overigen alleen maar over oorlogsschade praatten. Alle getuigen hebben als volwassen mannen natuurlijk de SintElizabethsvloed van 1404 beleefd, en kunnen daarover dan ook als ooggetuigen vertellen. Doch daar de periode waaraan Sint-Baafs zich interesseerde de afgelopen 40 jaar omvat - "inundationes maris que $a X L$ annis citra in Flandria fuerunt" heet hier de steeds weerkerende formule was het wel moeilijk om betreffende het jaar 1375 getuigen te vinden, die in dàt jaar al volwassen en bovendien ook nog ter zake bevoegd waren. Toch heeft men die moeilijkheid weten te overwinnen. Men kan uit het document ook opmaken dat alle getuigen door de Sint-Baafsabdij zelf werden aangeduid.

1. Michael de Busco alias dictus Cornelii, 80 jaar, kapelaan van de Heilig Kerstkerk te Gent ${ }^{5}$. Hij kent de abdij en haar geestelijken al 70 jaar lang $(a$ tempore quo ipse quasi decem erat). Overigens is hij zelf een tijdlang in het klooster aldaar geweest, en weet hij inlichtingen te geven over de Ambachten Aardenburg, Oostburg en Ijsendyke, evenals over de eilanden Cadzand en Wulpen, alsmede over de Vier Ambachten. Hij beweert ook ooggetuige geweest te zijn van de toestand die heerste op het riviereiland Weert bij Temse (sibi bene et veraciter constare occulata fide...). In de Vier Ambachten is hij echter zelf als afgevaardigde van Sint-Baafs meermaals bij dijkwerken aanwezig geweest (sepius ad huiusmodi aggeres confirmandos ex parte dicti monasterii deputatus), en heeft er eveneens in naam van de abdij vaak betalingen verricht (sumptus...nomine eiusdem monasterii solvit). Deze feiten, te zamen met zijn leeftijd, maakten hem tot een deugdelijke getuige.

2. Johannes de Goeselaere, 50 jaar, pastoor van de Onze-Lieve-Vrouwekerk te Sluis ${ }^{6}$. Hij kent al 20 jaar lang het klooster en zijn monniken, want hij 


\section{H. D. MEYER}

heeft er verbleven. Voor de tijd omstreeks 1375 is hij echter geen eigenlijke ooggetuige, en daarom beroept hij zich op wat hij gehoord heeft "a tam gravibus et veridicis personis quod eis merito fuit et est fides". Hij weet te vertellen over Cadzand, Wulpen, Biervliet, Wevelswale en over Weert. In de tijd toen hij nog zelf in het klooster was, is hij, net zoals de vorige getuige, afgevaardigde voor het onderhoud van de dijken geweest, en gaf hij als zodanig onderrichtingen aan hen die de werken moesten uitvoeren (ad diversas personas cura et custodia aggerum huiusmodi oneratas missus fuit). Uit een en ander kan men dus opmaken, dat hij misschien van kort na 1390 in die funktie bedrijvig was en dus uit eigen aanschouwing heeft kunnen beoordelen wat er nog te zien was van de vroegere schade.

3. Balduinus de Curia uit Gent, 65 jaar. Als funktie geeft hij op "receptor adpresens bonorum dicti monasterii consistentium in Quatuor Officiliis Flandrie videlicet de Bouchoute, Assenede, Hulst et Axele" 7 . Het is weinig waarschijnlijk dat hij al in 1375 ontvanger zal zijn geweest, maar hij is alleszins toch iemand die alle vloedrampen sedert 1375 mee heeft beleefd, en ze met kennis van zaken heeft kunnen beoordelen. Vandaar dan ook dat hij dezelfde formule gebruikt als andere gelijkaardige getuigen: "se bene recordari de illa magna maris inundatione que XXXVI vel XXXVII annis vel circiter elapsis in Flandria fuit". Het spreekt overigens vanzelf, dat hij juist door zijn ambt de meest precieze inlichtingen over de schade door de overstromingen in de Vier Ambachten veroorzaakt, kon krijgen. En dat hij die mogelijkheden ook daadwerkelijk heeft benut. Binnen de Vier Ambachten zelf bericht hij meer bepaald over de nabije en verre omgeving van Biervliet, doch hij geeft daarenboven nog inlichtingen over de Ambachten Aardenburg, Oostburg en Ijzendijke, alsook nog apart over Cadzand en Wulpen. Door dit alles onderscheidt de man zich als een van de getuigen wiens informatie het breedst en het meest diepgaand is.

4. Johannes de Boeyeghem, 61 jaar, uit Aardenburg, schepen van het Brugse vrije ("scabinus Franci territorii Flandrie") ${ }^{8}$. Ook hij beweert uitdrukkelijk zich nog alle belangrijke overstromingen sedert de katastrofe van 1375 goed te herinneren. Hij bespreekt de schade in de Ambachten Aardenburg,

7 Fol. 6r-8r. Dit is Boudewijn Utenhove, die de jaarrekeningen van de bezittingen in de Vier Ambachten voor a jaren 1395-1414 heeft opgemaakt (K 2308; ook K 8994 van 1405-06).

8 Fol. 8r-10r. Zijn familie was zeker woonachtig op Cadzand. We vinden in ieder geval de naam Jan van Boeyeghem daar in 1399/1400 (R 83/10), 1413 (R 790 fol 15r: "Pieter f. Jans van Boeyeghem"), alsook nog omstreeks 1435 (Leenboek van de Burcht van Brugge). Hijzelf was herhaaldelijk lid van de delegaties van het Brugse Vrije in het college der Leden van Vlaanderen tussen 1405 en 1414, cf. Zoete, A. Handelingen van de Leden en van de Staten van Vlaanderen (1405-1419). Excerpten uit de rekeningen der steden, kasselrijen en vortelijke ambtenaren. Deel II, Brussel 1982, 1436. 


\section{NIEUWE GETUIGENISSEN OVER STORMVLOEDSCHADE IN Z-V}

Oostburg en Ijzendijke, en ook hij vernoemt speciaal Cadzand en Wulpen. Verder heeft hij het over de ruimere omgeving van Biervliet. Overigens valt het op, dat men hem als getuige heeft genomen wegens zijn speciale inlichtingen over de toestand op de twee eilanden en ook over de situatie bij Biervliet. Dat nu net hij over deze streken op de hoogte is, kunnen we best verstaan voor Cadzand; maar voor Biervliet blijkt dit uit niets. Nochtans krijgen zijn uitweidingen over Biervliet wel een eigen tint, omdat hij zich een oog- en oorgetuige kan noemen van abt Johannes (III) (1351-1394) ${ }^{9}$ (nam ipsemet testis ut dicit vidit et audivit quod dominus Johannes dicti monasterii abbas predecessor videlicet predicti domini Walteri...).

5. Johannes de Damme, 53 jaar, pastoor van Oosterzele ${ }^{10}$. Hij verbleef lange tijd in de abdij en herinnert zich nog zeer goed de overstromingsrampen van de voorbije veertig jaar. Hij geeft inlichtingen over het Brugse Vrije, de Vier Ambachten en over het eiland Weert. Zijn kennis van de plaatselijke omstandigheden heeft hij opgedaan toen hij in opdracht van Sint-Baafs mee de leiding had van de herstellingswerken. Hierdoor ook had hij inzage gekregen van de betreffende rekeningen, en was hij voortreffelijk op de hoogte van de omvang van het verlies aan inkomsten voor de abdij, alsook van de stijging van haar uitgaven, beide veroorzaakt door de waterschade: "...ita in computationibus censarum et proventuum predictorum bonorum ac sumptuum et proventuum huiusmodi ab eorum censitoribus factis clare vidit contineri".

6. Paulus f. Walteri filii Balduini, 55 jaar, uit de gemeente Cadzand ${ }^{11}$. Hij is onze voornaamste en betrouwbaarste bron over alles wat zich op Cadzand heeft afgespeeld, en hij is de eerste van de drie hoofdgetuigen voor dit gebied. Door zijn leeftijd heeft hij natuurlijk als ooggetuige alle gebeurtenissen aldaar meegemaakt, want hij heeft zijn leven lang in Cadzand gewoond. Hij heeft alle stormvloeden op Cadzand en Wulpen beleefd (dicit se plures dampnosas maris inundationes $a X L$ annis circa in Flandria vidisse et presertim in territorio de Cadsand et de Wulpen), en hij kent eveneens de toestand van vóór 1375 (se bene recordari et etiam vidisse dicit ante predicta(s) inundationes...). Daar hij bovendien zelf grondbezitter is, is hij. zeer goed op de hoogte van de aangrenzende bezittingen, met name hoeveel grondeigendom Sint-Baafs bezit, maar ook welke de vroegere inkomsten van de abdij waren en wat daar nog van overgebleven is: "cum ipse ut dicit a tempore sue iuventutis in dicto territorio de Cadsand commoratus fuerit...et quasi omnes terras necnon decimas predictas bene noverit et adhuc

9 Jean Bemier De Fayt, cf. Berings, Lebbe, 54-56.

10 Fol. 10r-12r.

11 Fol. 12r-13r. Hij zal pachter "Pouwels f. Wouters f. Boudins" zijn (bv. R85 van 1421/22 fol 23r, maar ook reeds R83/10 van 1399/1400), en had wellicht eveneens een funktie in de Tienhondertpolder (R84/5 fol 20r van 1410). 
superessentes ibidem bene noscat...". Als landeigenaar die ook gronden verpacht is hij ook zelf dubbel getroffen door de vloedschade. Inderdaad is enerzijds een deel van zijn landerijen verloren gegaan, omdat hij zelf de onkosten van de bedijking niet meer had kunnen dragen, waardoor hij hoogstwaarschijnlijk verplicht is geweest grond over te laten aan "leggers", dit zijn financieel sterkere bedijkers dan hijzelf (...ipsemet testis...certas suas terras de quibus dudum septem libras gross. annuatim habere solebat eo quod ipse supportare non potuit onera huiusmodi omnes perdidit et amisit). En anderzijds krijgt hij nu voor zijn overgebleven pachtland nog maar $20 \mathrm{~s}$. par., terwijl dit hem vroeger $60 \mathrm{~s}$. par. opbracht per jaar en per gemet. Het is dus duidelijk dat deze man, met zijn uitgebreide kennis van de streek van Cadzand uitermate geschikt was tot het vellen van een oordeel, en dat SintBaafs voor haar doel met hem een uiterst goede keuze had gedaan. Een pluspunt voor hem was daarenboven het feit, dat hij niet behoorde tot de kring van hen die nauw in betrekking stonden met de abdij.

7. Johannes Baye, 65 jaar, uit Cadzand ${ }^{12}$. Hij is opgeroepen om als ooggetuige uitdrukkelijk de beweringen van zijn streekgenoot Paulus te bevestigen, en er nog enkele details uit zijn eigen ervaringen aan toe te voegen. Toen ook naar zijn persoonlijke mening werd gevraagd, oordeelde hij dat Sint-Baafs er beter aan zou doen sommige zwaar belaste gronden bij de zee op te geven (iudicio suo dicto monasterio valius esset...).

8. Andreas $f$. Johannis filii Hugonis, 70 jaar ${ }^{13}$, ook van Cadzand en eveneens opgevorderd om de beweringen van getuige Paulus te bevestigen. Hij is eveneens iemand die goed op de hoogte is van het grondbezit van het klooster evenals van de tiendopbrengsten te Cadzand. Ook hij is van oordeel dat het ekonomisch beter zou zijn "...aliquas terras proprias circa mare iacentes dimittere quam eas cum oneribus perinde supportandis retinere". Met hem zijn aldus drie kenners van het bezitscomplex van Sint-Baafs op Cadzand en Wulpen uitvoerig aan het woord gekomen.

9. Christoforus $f$. Willelmi Neves, 46 jaar, uit Aardenburg ${ }^{14}$. Hij is de eerste van zes getuigen, die over bijzonderheden betreffende de ambachten Aardenburg, Oostburg en Ijzendijke gehoord werden. Gezien zijn leeftijd kan hij enkel maar over de Sint-Elizabethsvloed van 1404 worden ondervraagd (...se bene scire quod per ultimas inundationes maris que fuerunt septem annis vel circiter elapsis...). In dit verband is hij weer een bijzondere getuige inzake Ijzendijke, omdat hij er tot 1404 gewoond heeft (a iuventute sua

12 Fol. 13r. R85 van 1421/22 fol. 19r vermeldt hem als ontvanger in de Tienhondertpolder.

13 Fol. 13r-13v. Dit kan een onjuist afgekorte naam zijn voor "Andries f. Jans f. Wouters f. Huughs" (zoals R83/10 fol 7v van 1399/1400). Dan was hij pachter van de abdij in Cadzand.

14 Fol. 13v-14v. 


\section{NIEUWE GETUIGENISSEN OVER STORMVLOEDSCHADE IN Z-V}

usque ad dictas ultimas inundationes et submersiones in parochia de Ysendike commorabatur). Hij beweert trouwens niet een slachtoffer van de watervloed te zijn, maar verklaart wel zijn verhuizing naar Aardenburg door het feit dat hij na de overstroming niet meer te Ijzendijke kon blijven wonen ("post submersionem huiusmodi ibidem diutius remanere nequiens").

10. Johannes Coc, 65 jaar, kapelaan van de Onze-Lieve-Vrouwekerk van Aardenburg ${ }^{15}$. Hij moet weliswaar beschouwd worden als een ooggetuige voor 1375, maar daarover wordt hij helemaal niet ondervraagd. Hij wordt eigenlijk veeleer opgeroepen om met cijfers de schade te staven die veroorzaakt was in de ambachten van West-Zeeuws-Vlaanderen. Opvallend daarbij is dat zijn gegevens over de schade in het ambacht Ijzendijke de meest precieze zijn. Zijn inlichtingen heeft hij gehaald bij de ontvangers van de goederen van Sint-Baafs en bij de inwoners van ljzendijke, maar meer nog uit de boekhouding van de abdij zelf en uit haar goederenregisters. Bovendien valt hij als ooggetuige op met betrekking tot een opvallende bijzonderheid, namelijk de maatregelen die voor de beveiliging van de abdijhoeve Altena tegen wateroverlast dienden te worden genomen. Hij is de enige getuige die over de bedreiging van dit goed spreekt en over het kommentaar dat de huidige abt over die kwestie gaf.

11. Franco Vos, 61 jaar, uit Moorskerke ${ }^{16}$. Om te beginnen bevestigt hij de inlichtingen van zijn voorganger, $\mathrm{Coc}$, en voegt er de details aan toe waarvan hij speciaal goed op de hoogte is. Hij is namelijk een pachter van de abdij waarvan hij grond heeft gepacht, die tot de Sint-Baafsparochie te Oostburg behoort, zodat hij precieze getallen kan opgeven over zijn vroegere en huidige pachtsom. Als pachter is hij bovendien ook getroffen door de vloed, want een deel van zijn gepachte landerijen werden overstroomd en zijn praktisch geheel verloren ("omnino perdita"). Wat hem aan pachtland rest (que ut permittitur ad censam tenet), wordt nog steeds door de zee bedreigd. Hij houdt er dan ook rekening mee dat hij nog delen ervan zal verliezen.

12. Johannes Noenbroet, 50 jaar, uit Aardenburg ${ }^{17}$, bevestigt alleen maar de inlichtingen van getuige Coc aangaande de verliezen geleden door Sint-Baafs in de Ambachten Aardenburg, Oostburg en Ijzendijke, zonder er zelf nog iets aan toe te voegen.

13. Walterus Baetman, 40 jaar, uit Aardenburg ${ }^{18}$. Uiteraard herinnert hij zich niets van de vloed van 1375 , maar wel van latere stormvloeden, meer

15 Fol. 14v-15v. In 1402 wordt hij als kapelaan van Sint-Baafs te Aardenburg genoemd, in 01485 (1402.07.16).

16 Fol. 15v-16r. Wat over hem en zijn familie zou kunnen gezegd worden, zou ons hier te ver leiden. Ik hoop dat elders te kunnen behandelen. De inventaris in het R.A.G. bevat de verkeerde lezing Moerkerke (sic) voor Moorskerke (het huidige Groede in Zeeland).

17 Fol. 16r-16v.

18 Fol. 16v-17r. 


\section{H. D. MEYER}

bepaald die van 1404 . Hij blijkt over zeer precieze gegevens te beschikken. Met name kan hij juiste cijfers opgeven (specificando dicit id testis...) betreffende de landverliezen in het Ambacht Ijzendijke evenals over het verlies aan tiendopbrengsten in de Ambachten Aardenburg en Oostburg. Waar hij die getallen vandaan heeft, is echter niet duidelijk. Men heeft hem echter blijkbaar speciaal laten komen, om ook hem te horen zeggen wat andere getuigen eveneens al beweerd hebben, namelijk dat hij die zwaarbelaste gronden van het klooster zelfs niet gratis zou willen aanvaarden: ("...quod ipsum monasterium aliquas terras in dicto officio Ardenburgensi retinuit et adhuc possidet quas ipse testis mallet non habere quam habere cum oneribus").

14. Amoldus van Oostende, 48 jaar, pastoor van Sint-Baafs te Aardenburg ${ }^{19}$. Hij verklaart de verschillende stormvloeden en de daaruit ontstane verwoestingen, in de laatste 40 jaar voorgekomen, zich nog goed te herinneren. Dat dit ook voor de tijd van omstreeks 1375 geldt, kan men geredelijk doch alleen in zeer algemene zin aanvaarden. Vandaar dat men de door hem geciteerde getallen over landverliezen in Ijzendijke slechts voor 1404 kan aannemen, of dat men achter die getallen de vermelde vertrouwenswaardige personen ("personae fidedignae") moet zoeken. In ieder geval is het duidelijk, dat men hem als deskundig beschouwt omdat hij, bij het citeren van de cijfers over de geschotbelasting, melding maakt van eigen grond, gelegen naast die van het klooster en even zwaar belast door schade (...habere certas terras proprias iuxta huiusmodi dicti monasterii terras iacentes similiter oneratas et dampnosas). Het gaat hier dus weer over iemand van de streek zelf die met kennis van zaken spreekt.

15. Jacobus Vits, 37 jaar, pastoor van Hannekenswerve ${ }^{20}$. Het vernoemen van zijn funktie is voor deze tweede jongste getuige, afdoende om zijn hoedanigheid en zijn kompetentie in dezen te erkennen. Hij is inderdaad algemeen ontvanger van de goederen van Sint-Baafs binnen het Brugse Vrije ("receptor generalis bonorum dicti monasterii in dicto Franco territorio

19 Fol. 17r-18r. Dat hij reeds lang betrekkingen had met Sint-Baafs, bewijst 01457 (1339.07.25). Hij krijgt opdracht, te zamen met nog anderen, achterstallige schulden voor het klooster op te halen. In bovenstaande noot 17 vermelde oorkonde verschijnt hij als getuige. Rekeningen van vele jaren zijn door hem opgemaakt ( $K$ 8073; 8074; R757/1; R757/2). Al in 1396 had hij een huis van de abdij gehuurd (R83/6 fol 4r).

20 Fol. 18r-18v. Er zijn talrijke bewijzen voor zijn aktiviteit voor St.-Baafs. Met oorkonde 01439 (1398.03.11) doet hij afstand van de erfenis van zijn oom (zijn voorganger als ontvanger) Willem van den Ackere. Hij heeft de rekeningen van het jaar 1410/11 opgemaakt (R84/6).

Ook deze oom heeft talrijke sporen nagelaten van zijn omvangrijke administratieve aktiviteiten voor Sint-Baafs. Zo is o.a. de komplete jaargang van de rekeningen van 1384/85 (rol 114) van zijn hand; 01406 (1395.05.05) is een akte over zijn testament; 01418 (1396.01.14) gaat over zijn nalatenschap. 


\section{NIEUWE GETUIGENISSEN OVER STORMVLOEDSCHADE IN Z-V}

Flandrie consistentium"). Natuurlijk weet hij niets meer af van de eerste grote overstroming (1375) ("prima magna inundatio"): hij zegt daarover trouwens zelf, dat hij geen juiste notie over de verliezen van toen meer hebben kàn. Dit tekort wordt echter terdege goedgemaakt doordat hij later, toen hij in de abdij verbleef als ontvanger oorkonden en bewijsmateriaal uit die tijd heeft nagegaan in registers en rekeningen, waardoor hij weet wat de abdij vóór de overstromingen bezat en wat ze nu nog heeft ("per ea que postquam in dicto monasterio conversatus est et eidem servivit in antiquis libris et registris ac computationibus bonorum que dictum monasterium ante dictas inundationes habuit et adhuc habet contineri vidit"). Hetgeen hij echter niet in deze bewijsstukken heeft kunnen vinden, is hij nochtans te weten gekomen dank zij betrouwbare zegslieden, vooral door zijn intussen overleden oom Willem Van Den Acker, die tevens zijn voorganger was in het ambt van ontvanger der Sint-Baafsgoederen in het Vrije ("...a bone memorie domino Willelmo de Agro condam avunculo suo et dictorum bonorum videlicet in dicto Franco territorio consistentium condam receptore nunc defuncto..."). Zijn kompetentie kan derhalve ook niet voor de tijd van vóór 1375 in twijfel worden getrokken. Overigens formuleert hij zijn uitspraken zeer kort en bondig.

16. Johannes Rasscaert, 80 jaar, uit Gent ${ }^{21}$. Deze bejaarde getuige verklaart, dat hij zich nog alle grote overstromingen die zich sedert 1375 in het gebied van de Vier Ambachten hebben voorgedaan, kan herinneren. Trouwens, in deze aangelegenheid is ook hij een speciale getuige: hij woonde namelijk in 1375 ("tempore prime magne inundationis que fuit XXXVII annis vel circiter elapsis") in het Ambacht Assenede, meer bepaald in de parochie Steeland en wel in een hoeve die toebehoort an de abdij ("in quadam curte seu possessione ad dictum monasterium pertinente"). Merkwaardig bij dit alles is, dat hij de naam van de hoeve van Sint-Baafs niet vermeldt, hoewel het hier ongetwijfeld over de hof Vogeldijk gaat, die immers Sint-Baafs toebehoorde. Hij was er zelf de pachter van en had door de stormvloed zware schade geleden. Overigens is hij ons ook bekend door de pachtovereenkomst die hij in 1377 betreffende Vogeldijk had afgesloten ${ }^{22}$. Vermoedelijk was hij de enige nog levende pachter van Sint-Baafs uit die vroege tijd en was hij juist daarom opgeroepen als getuige.

In het verslag over het getuigenverhoor volgt dan een groep van zeven getuigen, die evenwel allen over de gevolgen van oorlogshandelingen en

21 Fol. 18v-19v.

22 Vgl. Gottschalk, Vier Ambachten 307; Verhulst, Grondbezit 499; verder de talrijke vermeldingen in K 2308. De aldaar (p. 63) na 1397 vernoemde Cornelis Rasschaert zal zijn zoon zijn. Maar of hij op het tijdstip van de ondervraging van de getuigen nog pachter van Vogeldijk was, is onzeker. Het is begrijpelijk dat men de oudere man liever had als getuige. 


\section{H. D. MEYER}

over vernielingen toegebracht aan gebouwen handelen. Daarom laten wij ze hier buiten beschouwing. Tenslotte komen als laatsten drie getuigen aan het woord, die het uitsluitend hebben over het riviereiland Weert.

17. Nicolaus de Versierere, 65 jaar, uit Temse. Deze inwoner van Temse, van wie niets over funktie of herkomst wordt gezegd, blijkt bij nadere beschouwing een inwoner van het eiland te zijn ${ }^{23}$. In ieder geval is hij klaarblijkelijk uitgenodigd als expert voor alle technische en financiële aangelegenheden, die verband houden met de precaire ligging van het eiland Weert tussen Durme en Schelde, zowel wat de beveiliging tegen hoogtij betreft als wat de afwatering aangaat. Ook al was hij zelf inwoner van het riviereiland, toch wijzen de biezonderheden die hij erg kompetent naar voren brengt erop dat hij op de een of andere wijze ambtelijk met dijkbouw moet te maken hebben gehad. Zo kent hij de opbrengsten van de landerijen van SintBaafs vóór en na de overstromingen; hij signaleert details over de bedijking; hij weidt uit over de uitgaven voor de aanleg van dijken, en vooral van sluizen; uiteindelijk berekent hij zelfs al voor de komende vier jaren, hoe slecht de vooruitzichten inzake opbrengst zullen zijn. Bij al dit is het opvallend, dat getuige ertoe is aangezet om de toestand uitvoerig te beschrijven, want hij is waarlijk de enige die zó uitgebreid aan het woord komt. Dit laat ons wel de indruk na, dat men vreesde dat de problemen van een riviereiland zoals Weert, allicht niet zeer ernstig zouden worden genomen in vergelijking tot stormvloeden. Voor het overige ligt het voor de hand, dat deze zegsman alleen al ruim volstond om alle vragen in deze aangelegenheid te beantwoorden.

18. Johannes Roeland, 50 jaar, en 19. Johannes Dullaerd, 28 jaar, alle twee uit Temse ${ }^{24}$. Beiden bevestigen enkel maar wat vorige getuige heeft gezegd en voegen er niets aan toe.

De karakterisering van de ontboden getuigen heeft duidelijk gemaakt dat de kloosterleiding groot belang hechtte aan deze aangelegenheid en het hele vertoon met de getuigen zeer gerechtvaardigd achtte, met het oog op de som die op het spel stond. Daarenboven zien we aan de keuze van de getuigen, dat men zich bewust was van de voorwaarden die moesten vervuld worden wilde men sukses hebben. De abdij heeft zich in ieder geval ingespannen geestelijken en leken van allerlei rang in te schakelen en daarbij drie kriteria

23 Fol. 21v-22r. Ettelijke pachters van St.-Baafs in Weert behoren blijkbaar tot deze familie (K2533 fol. 9r, 31r, 31v). Dat de onder hen vernoemde Claus (sic) de Visierre onze getuige zou zijn, is het overwegen waard. Over Weert, cf. ook Nicholas, D., Weert: a Scheldt polder village in the fourteenth century, in Journal of medieval history 1976, 239-268. We aanvaarden evenwel niet de stelling dat Sint-Baafs slechts twee derden van de oppervlakte van het eiland bezat, zoals Nicholas uit de tienden afleidt.

Fol. 22r. 


\section{NIEUWE GETUIGENISSEN OVER STORMVLOEDSCHADE IN Z-V}

in het oog gehouden: ze moesten ooggetuigen zijn, de streek kennen en vakkennis bezitten, evenals inzicht in de abdijfinanciën op basis van geschreven dokumenten. Uiteraard waren getuigen welkom die meerdere van deze kompetenties bezaten. Het resultaat van al deze inspanningen is duidelijk. Drie geestelijken werden als getuigen opgeroepen, die in opdracht van de abdij mee de leiding hadden gehad van werkzaamheden inzake bedijking en drooglegging en die daartoe minstens ten dele inzicht hadden in de financiële verrichtingen ter zake. In drie gevallen steunt de informatie direkt of indirekt op ontvangers van de Sint-Baafsabdij. Twee leken zijn pachters van abdijgoederen en hadden ieder een grote hoeve in pacht. Eén geestelijke was als grondbezitter buurman van de abdij en verpachtte vermoedelijk zijn land. Een leek die eveneens eigenaar was, deelt mee dat hij zijn bezit verpacht. Al bij al kunnen we hieruit besluiten, dat er genoeg kompetente getuigen waren om alle vragen over de overstromingen van 1375 en 1404 te kunnen beantwoorden.

\section{a. De Ambachten Aardenburg, Oostburg en Ijzendijke.}

Deze streek willen we zonder Cadzand en Wulpen behandelen zoals dit ook bij het getuigenverhoor is gebeurd. Beide eilanden nemen inderdaad een aparte plaats in, zodat hun indeling bij een ambacht van bijkomstig belang is. Getuige 11 geeft aanvankelijk enkel maar inlichtingen over de toestand in het Ambacht Oostburg, en dan nog alleen, precizeert hij nog, over de parochie Sint-Baafs. Hij verduidelijkt de verliezen van de abdij, net zoals andere getuigen dit telkens weer doen en zoals het trouwens de bedoeling van de ondervraging was, niet met het vermelden van een globaal bedrag, maar wel met cijfers die het verliespercentage laten uitkomen. Zo betaalde hij als pachter o.a. voor een bepaald stuk land van de abdij 30 pond (de oppervlakte geeft hij niet aan, waardoor we niet weten of de pacht hoog of matig was), terwijl hij er op dit ogenblik nog ten hoogste 14 pond voor betaalt en soms nog minder (non plus quam XIIII libras annuatim) ${ }^{25}$. Dit brengt het verlies aan pachtinkomsten voor de abdij tot ruim de helft. Een deel van zijn pachtland ligt nog op een andere plaats dan deze in waarde gedaalde grond en daar het gedeeltelijk is overstroomd en gedeeltelijk bedreigd is, vreest de man binnenkort ook hiervan minstens nog een deel te zien verloren gaan. Hiermee bedoelt hij, dat dit opnieuw een verlies aan pachtinkomsten voor de abdij betekent, met name nog een vermindering van de reeds krappe helft. Al deze gegevens zijn overzichtelijke vaststellingen die de situatie in 1412

25 Fol. 15v. 


\section{H. D. MEYER}

verduidelijken, d.w.z. aan het einde van de periode van $\mathbf{4 0}$ jaren waarover het hier gaat. Ze kunnen dus niet op een bepaalde gebeurtenis noch op een bepaalde datum betrokken worden.

Bondig en beslist heeft getuige 4 het over Ijzendijke: de abdij verloor onherroepelijk alle tienden, gronden, weilanden, meersen en andere goederen die ze bezat in het Ambacht Ijzendijke ("amisit insuper...dictum monasterium irrecuperabiliter omnes decimas necnon terras prata pascua et alias possessiones quas precipue in dicto officio de Ysendike...habebat $\left.{ }^{\prime \prime}\right)^{26}$.

Zo samengebald kan de situatie in het Ambacht Oostburg niet worden voorgesteld, want in plaats van over het gehele ambacht wordt er alleen met name melding gemaakt van twee parochies die getroffen zijn, namelijk SintBaafs te Oostburg zelf, en Sinte-Margriete bij Oostburg. Tegelijk worden landerijen in deze omgeving beschreven, waarvan als grens wordt opgegeven: tot aan de Waardijk ("usque ad aggerem sive dicum dictum Ware"). Daarmee beschikken we over een zeer welgekomen expliciete bevestiging en vervollediging van bekende impliciete vermeldingen van het feit, dat het water doorgedrongen was tot aan de Waardijk ten oosten van Aardenburg. Die dijk zal wellicht maar een opgehoogde dam zijn geweest die als weg werd gebruikt. Men krijgt de indruk dat de getuige het hier heeft over de overstroming van 1375, maar zekerheid daarover hebben we niet, want ook deze mededeling is slechts vrij algemeen.

Hier duikt plotseling een verwijzing op naar een mogelijkheid van bewijs, met name naar een ooggetuigenverslag ter plaatse zelf: "dat de overstroming van genoemde gebieden zo duidelijk zichtbaar is zodat geen twijfel daarover bestaat of kan bestaan vermits de torens en muren van meerdere overstroomde kerken nu nog in de zee schijnen te staan ("quod predictarum partium submersio ...est notoria et manifesta quod nullum inde dubium illic existit et esse potest cum turres et muri plurium ecclesiarum submersarum adhuc in mari stare videantur" ${ }^{27}$. Het is net alsof hij met twijfelaars te maken heeft, die het katastrofale karakter van de gebeurtenissen niet zo maar willen aanvaarden. Dergelijke twijfelaars kunnen dan de waarheid van de beweringen over volledig verdronken dorpen zelf kontroleren, desnoods door na te tellen hoeveel kerktorens er nog boven het water uitsteken. Trouwens, eenieder die de Sint-Baafsabdij kent en de overstroomde landerijen, weet volgens deze getuige uit zichzelf genoeg hoe enorm groot de schade is. Maar, of ze wel zo groot is als de abdij in de betreffende paragraaf van haar verzoekschrift beweert, dat weet hij niet precies, en daarom bevestigt hij dit ook niet. Het resultaat van dit getuigenis was voor Sint-Baafs veeleer onbevredigend, niettegenstaande er met alle details rekening was gehouden, gezien het er op aan kwam het bewijs te leveren dat de helft van de vroegere

\footnotetext{
26 Fol. 8v-9r.

27 Fol. 15r.
} 


\section{NIEUWE GETUIGENISSEN OVER STORMVLOEDSCHADE IN Z-V}

inkomsten verloren was gegaan. Men heeft getuige 4 blijkbaar tot een Salomonsoordeel bewogen om hem te doen vasthouden aan deze helft. Indien hij zelf voor de keuze zou worden gesteld om, of de helft van de vroegere inkomsten van de abdij te incasseren ofwel alle huidige inkomsten te verkrijgen, zou hij inderdaad - zo verklaarde hij - het éérste verkiezen. Immers alle goederen van vandaag "omnia bona" bedragen minder dan de helft van de goederen ("medietas bonorum") van vroeger. Er zijn evenwel ook nog andere aanzienlijke, hoewel niet becijferbare verliesposten. In het Ambacht Aardenburg bijvoorbeeld, bijkomend het wegvallen van de toch al erg geslonken inkomsten van de tienden. Deze verliezen worden niet becijferd maar verantwoord, want ze ontstaan en groeien nog bestendig aan omdat de tiendplichtigen steeds vaker van hun verplichtingen ontheven moeten worden met het doel hen in het land te houden ("ad retinendum eos in patria"). Er dreigt dus ontvolking in deze gebieden indien het met de abdij zodanig slecht gesteld is, dat ze zich dergelijke grootmoedigheid niet meer zou kunnen veroorloven.

Om het verlies van produktie op het overgebleven land te ramen, alsmede voor een beoordeling van de tiendinkomsten, die immers afhankelijk zijn van de produktie, geeft getuige 4 ons tot slot nog enkele getallen. De hele tijd tussen 1381 en 1385 heeft hij de landgoederen van de Sint-Baafsabdij in de ambachten Aardenburg en Oostburg zien braak ligggen. Doordat hij deze jaartallen opgeeft, is het duidelijk dat hij het heeft over de gevolgen van de overstromingen van de jaren zeventig. Overigens beweert onze zegsman niet dat het over het hele grondbezit van de abdij gaat. Klaarblijkelijk vond men het op zich al erg genoeg dat kloosterland, dat destijds tegen zulke hoge prijs was gewonnen, nu gewoon onbewerkt bleef liggen.

Getuige $10 \mathrm{komt}$ in zijn geraamde berekening van de overblijvende inkomsten van Sint-Baafs voor de Ambachten Aardenburg en Oostburg samen, op veel minder dan de helft uit, met name op een vierde van de opbrengst van 40 jaar geleden. Tenminste, als we zijn niet bepaald duidelijke verklaringen goed begrijpen. Hij schat de overgebleven bronnen van inkomsten namelijk gewoon op de helft van die van veertig jaar geleden ("quod predictum monasterium in dictis duobus officiis vix retinuit et adpresens possidet medietatem reddituum possessionum et aliorum bonorum que ante $X L$ annos ibidem possidere et habere solebat") ${ }^{28}$. Maar de opbrengst van de nu nog overgebleven basis schat hij - zoals wij het begrijpen - op basis van de inlichtingen van zijn eigen informanten, eveneens op de helft van datgene wat men veertig jaar geleden en voor de bewuste overstromingen van deze grondeigendommen had kunnen verwachten ("de bonis suis adhuc ibidem superessentibus nunc etiam vix medietatem illius

Fol. 16r. 


\section{H. D. MEYER}

recipit quod ante $X L$ annos et dictas inundationes et submersiones inde recipere consuevit"). Dit alles wordt ook uitdrukkelijk bevestigd door getuige 12, die op zijn beurt de hoogte van de inkomsten van vóór veertig jaar berekent op het dubbele van hetgeen nu wordt ontvangen ("in duplo plus inde recepit quam nunc recipit") ${ }^{29}$.

Door getuige 13 wordt een precies bedrag meegedeeld voor het tiend van Sint-Baafs in Aardenburg en Oostburg. Dit bedrag houdt echter alleen rekening met het verlies van 1404, en niet met de verliezen geleden door vroegere overstromingen. De abdij verloor o.a. genoemde tienden ter waarde van $30 \mathrm{lb}$. tournois of daaromtrent: ("amisit inter cetera dictas decimas que singulis annis $\mathrm{XXX}$ (lb.) torn. vel quasi valere solebant") ${ }^{30}$.

Getuige 14 becijfert dan weer de omvang van het verlies der abdij op een goede helft van haar inkomsten uit cijnzen en renten en uit andere goederen ("bene medietatem reddituum et aliarum possessionum suarum") ${ }^{31}$. Verder bewijst hij met exacte cijfers het verschil tussen ontvangsten voor bepaalde gebieden (berekend per gemet) en uitgaven, die alleen voor bedijking ("pro dicagio") te presteren zijn: bij een pacht van 10 s.par. bedraagt het geschot 12 s.par.! Hij weet dit overigens zo precies, omdat hijzelf land naast het kloosterland heeft liggen, in dezelfde polder dus, en hij evenveel moet betalen. Alle verdere onvermijdelijke en noodzakelijke uitgaven vergroten uiteraard het jaarlijkse deficit.

Het hoger reeds aangehaalde getuigenis van zegsman 4 over het verlies van alle inkomsten in het Ambacht Ijzendijke, wordt gestaafd door dat van getuige 9. Deze voegt er een lichte nuance aan toe, namelijk dat na de andere voornoemde overstroming weliswaar sommige gebieden waren gespaard gebleven, die echter daarna, door de overstromingen van ongeveer zeven jaar geleden ("per ultimas inundationes maris que fuerunt septem annis vel circiter elapsis") ${ }^{32}$, eveneens totaal en voor goed verloren zijn gegaan.

Getuige 10 spreekt zich zeer duidelijk, maar in een nogal kreupele zin, uit over het Ambacht Ijzendijke: daar het ambacht geheel overstroomd is en blijft ("cum officium ipsum totaliter sit...remaneat submersum") ${ }^{33}$. Hij weigert evenwel de inkomsten te specifiëren, omdat hij niet genoeg op de hoogte is ("eorum valorem et quantitatem precise specificare ignoret"). Dit betekent: hij weet er niet méér van dan wat hij reeds als richtgetal heeft opgegeven voor de hoeveelheid grondgebied die bij de Sint-Elizabethsvloed is teloorgegaan: namelijk dat het klooster alleen reeds in het ambacht Ijzendijke door voornoemde overstromingen een goede 120 gemeten eigen

$\begin{array}{ll}29 & \text { Fol. 16v. } \\ 30 & \text { Fol. 17v. } \\ 31 & \text { Fol. 13v; 14r. } \\ 32 & \text { Fol. 14v. } \\ 33 & \text { Fol. 14v. }\end{array}$


land verloor ("quod predictum monasterium solum in officio de Ysendike per inundationes et submersiones predictas bene centum et XX mensuras terrarum suarum propriarum irrecuperabiliter amisit") ${ }^{34}$. Hierdoor ontstaat echter wel een discrepantie met het getal van 224 gemeten, waarover getuige 13 het heeft en dat eveneens zeer nadrukkelijk betrekking heeft op het verlies in 1404 geleden in het Ambacht Ijzendijke. Hij verzuimt hierbij vooral niet die gronden als droog ("aride") en vruchtbaar ("multum fructuose") te roemen ${ }^{35}$. Nog een derde versie vertelt getuige 14 , die met schijnbare precisie beweert dat wel goed 124 gemeten van 's kloosters eigen land verloren gingen ("bene centum et XXIIII mensuras terrarum suarum propriarum"). Het is bij dit alles wel merkwaardig, dat die afwijkende uitspraken naast elkaar staan, ook al had de abdij ze in haar eigen voordeel kunnen korrigeren. Uit de rekeningen blijkt immers duidelijk dat het hoogste cijfer, aangehaald door getuige 13, het juiste is: "in Ysendike verdronken II XXIIII gemeten lands int jaer XIIII IIII" ${ }^{36}$.

Blijft hier tot slot nog het beknopte verslag van de algemeen ontvanger te bespreken, dat uiteraard summier het hele Brugse Vrije omvat, zoals we dit van deze kompetente verslaggever kunnen verwachten. Hij resumeert inderdaad de gebeurtenissen van de laatste 40 jaren aan de hand van zijn uitstekende schriftelijke en mondelinge bronnen, die we in onze inleiding reeds benut hebben, en hij beantwoordt de twee beslissende vragen, als volgt: a) het verlies is inderdaad op meer dan de helft ("ultra medietatem") van alle vroegere bezittingen te becijferen, en dit deel is werkelijk onherroepelijk ("irrecuperabiliter") verloren; b) de onkosten om het overgebleven gebied te laten renderen, overtreffen zeer vaak de opbrengst van meerdere jaren ("sumptus et expense... ultra valorem annuum plurium huiusmodi terrarum...se extendunt"). Dit wordt verduidelijkt door volgende sommen: de abdij krijgt momenteel hoogstens $10 \mathrm{~s}$. par. per gemet, terwijl ze daarvoor 12, 16 tot zelfs 20 s.par. per gemet moet uitgeven aan onkosten. Dit stemt dus goed overeen met hetgeen we uit de verklaringen van de diverse getuigen kunnen opmaken. Vandaar ook dat klaarblijkelijk deze verklaring voor het gehele gebied van het Brugse Vrije algemene geldigheid bezit en als slot van de afzonderlijke getuigenissen over dit gebied is geplaatst.

Alles bij elkaar genomen, heeft de hele uiteenzetting onloochenbaar bevestigd, dat het door de Sint-Baafsabdij vermelde cijfer helemaal klopt. Haar bezittingen in de Ambachten Aardenburg, Oostburg en Ijzendijke zijn na de stormvloeden tot "nauwelijks de helft" van het vroegere bezit herleid.

34 Fol. 16v.

35. Fol. 17r. De aangifte van geleden schade ( $R$ 85 van 1418/19) wordt daarna jarenlang nog herhaald in de rekeningen.

36 Getuige 15=fol 18r. 


\section{H. D. MEYER}

\section{b. Cadzand en Wulpen.}

De aparte aandacht die bij de ondervraging van de getuigen aan deze gebieden werd besteed, is te verklaren door de speciale belangstelling die Sint-Baafs ervoor had. De abdij bezat er niet enkel uitgebreid grondbezit, maar ze had er ook voor een deel het uitsluitende recht op tienden - wat overigens ook duidelijk naar voren komt uit de verklaringen van één van de getuigen, die zeer goed op de hoogte is van plaats en situatie. Aan deze feitelijke omstandigheid is het intussen te danken, dat de tot nu toe slechte overlevering met betrekking tot Cadzand en Wulpen, thans verbeterd kan worden. Meteen worden ook enkele merkwaardige feiten voor het eerst duidelijk.

Drie getuigen vermelden summier de stormvloedschade op Cadzand en Wulpen en beweren dat ze aanzienlijk was; zonder echter in details te treden ${ }^{37}$. Getuige 3 heeft het wèl over een som geld, zijnde het bedrag van de verliezen in de Ambachten Aardenburg, Oostburg en Ijzendijke, op Cadzand en op Wulpen. Deze belopen per jaar $2000 \mathrm{lb}$. par., zowel in tienden, gronden of andere bezittingen ("tam in decimis quam terris et possessionibus aliis") ${ }^{38}$. Ook dit is evenwel nog eens als resultaat van alle overstromingen samen bedoeld. Hierdoor blijft alleszins nog steeds de vraag open, niet alleen wat het aandeel van Cadzand en Wulpen in dat bedrag is, maar tevens ook op welk tijdstip de schade zo hoog is opgelopen. Het is weinig waarschijnlijk dat dit door één enkele vloed in 1375 gebeurde, zonder dat er later nog iets belangrijks zou zijn bij gekomen. Daarover wordt echter niets gezegd. Getuigen 4 en 6 geven nu een aantal speciale inlichtingen die bij gebrek aan andere getuigenissen, een enigszins meer uitvoerige behandeling vragen.

Het begint al meteen met de geografische situatie van het besproken gebied. Beide mannen hebben het over Cadzand en Wulpen niet als twee aparte eilanden, maar wel als twee territoria die samen één enkel eiland vormden ("in dictis territoriis de Cadzand et Wulpen que territoria ut idem testis dicit in una insula multum lata et ampla consistere solebant"). Getuige 6 laat ons in dezelfde zin ook nog eens nadrukkelijk zijn bekendheid met de behandelde streek horen: ("...de Cadzand et de Wulpen que duo territoria prout testis loquens se bene recordari et etiam vidisse dicit ante predicta(s) inundationes una insula bene habitata lata et multum opulenta...esse solebat") ${ }^{39}$.

Indien reeds enige tijd vóór 1375 de geografische situatie zo is geweest, dan moeten wij ons inzicht in de ontwikkeling ervan tijdens de eerste helft van de

37 Getuige 1=fol 2v; getuige 2=fol 5r, getuige 13-fol 16v.

38 Fol. $7 \mathrm{v}$.

39 Fol. 8v; $12 \mathrm{r}+\mathrm{v}$. 


\section{NIEUWE GETUIGENISSEN OVER STORMVLOEDSCHADE IN Z-V}

veertiende eeuw corrigeren. Immers, nooit heeft iemand er rekening mee gehouden dat er ooit een verbinding tussen de twee eilanden kan hebben bestaan. Door een verdrag uit 1290 tussen de betrokken partijen en uit Gent en Doornik over de verdeling der tiendgebieden in deze omgeving, wisten wij alleen dat de grens tussen Cadzand en Wulpen de "killa maior" was ("usque ad maiorem killam dividentem inter terras Wulpie et terras Cadzandie"), of zoals het ook elders luidt "tot de voornoemde kreek tussen Cadzand en Wulpen" ("usque ad crecam predictam inter Cadzant et Wulpia $\left.(m)^{\prime \prime}\right)$. Die kreek als grens bestond dus niet meer. Ze was wellicht ingepolderd, misschien slechts een smalle kreek tussen beide vroegere eilanden latend ${ }^{40}$. In ieder geval, hier raakten de beide territoria en tegelijk ook de Ambachten Aardenburg en Oostburg elkaar. Dit kan trouwens één van de redenen geweest zijn waarom men aan het onderscheid tussen de beide territoria Cadzand en Wulpen vasthield. Dit betekent overigens ook niet noodzakelijk, dat de twee gewezen eilanden nu over de gehele lengte van hun kust met elkaar verbonden zijn geweest. Dat is zelfs niet eens waarschijnlijk. Het zal al voldoende geweest zijn dat we aan de westkant een landbrug aannemen, die tamelijk breed zal geweest zijn. Juist dit nieuw gevormde grote eiland werd aan de stormvloed blootgesteld.

Wat de daarbij aangerichte schade aangaat, zo beschrijft getuige deze natuurlijk, zoals het zijn taak was, vanuit het standpunt van de verliezen voor de abdij. Omdat de inhoud van zijn verhaal een vèrstrekkende betekenis heeft, gaan wij er dieper op in ${ }^{41}$. Door deze mededelingen krijgen we immers voor de eerste keer een tamelijk duidelijk beeld hoe de katastrofe van de overstroming gebeurd is, alsook van het resultaat ervan. Allereerst stellen wij vast dat, naar te verwachten was, de twee territoria zeer verschillend getroffen zijn. Immers, kunnen we voor Wulpen werkelijk van een katastrofe gewagen, dan kunnen we voor Cadzand veeleer over zware schade spreken.

Het Wulpense gebied is volgens het getuigenis nagenoeg volledig overstroomd, met uitzondering van één enkele verhevenheid, waarop thans nog enkel een rest van de eertijds zo talrijke bevolking ellendig vegeteert. Nochtans blijft er nog plaats genoeg over om wat kleinvee te houden, zodat

40 0531 (1290.09.18). Volgende polders liggen in dit deel van Wulpen: de polder van de heer van Zekervliet, de Rascardpolder en de Zoeteminspolder. Merk wel, dat ook nog na de grote verwoestingen door stormvloeden de plaatsbepaling "in Wulpen an Cadzant" voorkomt (leenregister van Brugge van 1435, fol 41v).

41 "...omnes decimas de omnibus terris et fructibus decimandis plures quoque terras et alia bona proprias et propria quas in dicto territorio de Wulpen quasi omnes irrecuperabiliter amisit cum ipsum territorium totum excepta una parvula motula supra quam pauci pauperes homines cum besticulis eorum degunt submersum et a remanente et salvo territoria de Cadsand abdicatum existat. Amisit etiam similiter idem monasterium in dicto territorio de Cadsant...tertiam partem et ultra dictarum decimarum et aliorum bonorum omnium quas ibidem habebat". 


\section{H. D. MEYER}

we deze motte toch kunnen beschouwen als een wat meer uitgebreide natuurlijke verhevenheid van het eiland. Dus wel iets meer dan zo maar een vluchtheuvel.

Door de stormvloed is nu ook opnieuw de afscheiding van het naburige eiland Cadzand ontstaan, en hierover worden enkele merkwaardige biezonderheden vermeld. Zo heeft men het hier uitdrukkelijk over dat gebied van Cadzand dat het dichtst bij Wulpen ligt, en dat wordt beschreven als "gespaard en ongedeerd". Dit kan wel niet betekenen, dat Cadzand op deze plaats geen schade zou ondervonden hebben, en het alleen Wulpen zou geweest zijn dat landverlies had geleden op de invalsbres. Het betekent enkel maar dat de geleden schade op beide eilanden niet met elkaar te vergelijken is. Het resultaat wordt dan ook opvallend als volgt beschreven: "cum ipsum territorium...submersum et a remanente et salvo territorio de Cadsand abdicatum existat". Dit zal men moeten interpreteren in het licht van de situatie zoals die voordien had bestaan. Toen namelijk eertijds beide eilanden met dijken aan elkaar verbonden werden, waren er natuurlijk ook dijken gebouwd die het vroegere dijksysteem van beide eilanden met elkaar in verbinding brachten en aldus tegelijk de landbrug van terzijde beschermden. Welnu, laatstgenoemde dijken zijn samen met grote delen van de oude Hievendijk van Wulpen vernietigd, zodat de nieuwe situatie in hoger vermelde passus kan worden voorgesteld als "het land is overstroomd en heeft geen dijkverbindingen meer ("abdicatum") met het gespaard gebleven land van Cadzand".

We zien hier dus, met een duidelijk bewijs uit de bronnen voor dit konkreet geval, de voor de hand liggende opvatting gestaafd dat het eiland Wulpen sedert zijn ontstaan de noordzijde van het eiland Cadzand vaak als een golfbreker heeft beschermd tegen stormvloeden. Als we nu moeten aannemen, dat de hier beschreven vloedkatastrofe één van de meest ernstige stadia is geweest in het reeds voóór 1350 begonnen bestendige landverlies op Wulpen, ja misschien zelfs het ergste stadium hierin, dan kunnen we ons zonder moeite indenken dat het hier gaat om de teloorgang van het westelijke deel van het eiland. Want daar moet, naar het zich laat aanzien, de landbrug naar Cadzand gelegen hebben. Maar, wanneer is dat nu eigenlijk gebeurd ?

De verklaringen van de getuigen geven op dit punt echter even weinig uitsluitsel als in de meeste andere gevallen. Getuige $4 \mathrm{kan}$ als voorbeeld dienen. Weliswaar verwijst hij aanvankelijk naar de grote en verschrikkelijke overstroming door de zee ("magna et lamentabilis inundatio maris"), die hij overigens ook precies zes- of zevenendertig jaar geleden dateert ("que fuit $X X X V I$ vel XXXVII annis vel circiter elapsis"). Hij zegt dit aldus omdat bij zijn ondervraging als getuige in januari 1412, de gebeurtenis 36 jaren en 3 maanden geleden was. Maar, toen hij het over de details van de door de stormvloed veroorzaakte schade had, die we zoëven hebben vermeld, was hij 


\section{NIEUWE GETUIGENISSEN OVER STORMVLOEDSCHADE IN Z-V}

intussen al begonnen uit de weiden "over de verschillende andere stormvloeden die daarop waren gevolgd" ("de diversis aliis maris inundationibus postea secutis"), waarheen hij van dan af steeds verwijst .

Als voor de ingrijpende gebeurtenis van het verzwelgen van de westelijke kant van Wulpen een keuze moet worden gemaakt, inzake datering, tussen de enorme stormvloeden van 1375 of die van 1404, dan zal men om gegronde redenen de vroege datum moeten nemen. Ziehier waarom ${ }^{42}$.

Tegen een datering op 1404 spreekt alleszins het voor Cadzand fundamentele feit, dat de vroeger al overstroomde gedeelten van het eiland, die echter sedert 1399 teruggewonnen en tot een goed afgebakende grote polder waren bedijkt, in 1404 niet nogmaals ten onder zijn gegaan. We bedoelen hiermee vooral de in 1402 opnieuw ingedijkte doch zeer blootgestelde Tienhondertpolder, evenals de reeds in 1399 aangelegde Vierhondertpolderbezuiden-de-kerk die in het overstromingsjaar 1404 nog aan de zee lag, terwijl op dat ogenblik de Strijdersgatpolder nog niet opnieuw was bedijkt. Ook de in 1403 nieuw aangelegde Vierhondertpolder-bij-Ter-Hofstede behoort tot deze groep. Bij de beoordeling van deze situatie moet worden rekening gehouden met de ons bekende feiten over dijkbreuken, verlies van land en wederopbouwwerken op Cadzand tijdens de jaren negentig en rond 1400. Toen twee grote bressen in de noordelijke dijk van Cadzand werden geslagen, vrij zeker allebei in 1398, hadden de zware overstromingen van de gronden die nadien tot grote polders werden herbedijkt, reeds plaatsgevonden. Het verlies aan de oostelijke rand van het eiland, in de latere Strijdersgatpolder, moet een eerste faze zijn geweest. Daarna volgden, tot 1398, de gronden van de toekomstige Vierhondertpolder-bezuiden-de-kerk en van de Tienhondertpolder, want in 1399 wordt al begonnen met de terugwinning ervan. Uit dit alles blijkt overduidelijk dat voor Cadzand en zijn omgeving de kritieke jaren vóór de eeuwwisseling liggen, en dat de SintElizabethsvloed van 1404 voor Cadzand betrekkelijk onschuldig is verlopen. In dit vrij duidelijk te reconstrueren verloop van de overstromingen op het einde van de 14e eeuw, kan de ondergang van het westelijke deel van Wulpen alleen vroeg, d.w.z. in 1375, gesitueerd worden, hetgeen niet uitsluit dat nà die tijd nog andere stormschade werd aangericht. Dit verloop kan dan als volgt worden geschetst.

$\mathrm{Na}$ een lange fase van aanhoudend doch middelmatig landverlies, wordt in 1375 het westelijk deel van Wulpen door een katastrofale stormvloed vernield, waardoor de verbinding met Cadzand, die tijdens de eerste helft van de veertiende eeuw tot stand was gebracht, werd verbroken. Cadzand wordt weliswaar ook getroffen, maar niet ingrijpend; wel is het vanaf deze tijd

42 Ik ga niet dieper in op een zekere tegenspraak, die ik meen te vinden tussen Gottschalk HG1, 191 en 202, betreffende Cadzand en Wulpen. Bewust ga ik eveneens voorbij aan het ontstaan van het Zwarte Gat. 


\section{H. D. MEYER}

merkelijk sterker bedreigd. Wellicht reeds na 1380, maar zeker na 1390 , lijdt Cadzand de zwaarste schade uit zijn geschiedenis. Nagenoeg een derde van zijn oppervlakte gaat verloren. Tussen 1399 en 1403 echter wordt het verlies aan grondgebied weer bijna goedgemaakt en de stormvloed van 1404 heeft generlei invloed gehad op die vooruitgang. Een definitieve verbinding van Cadzand met Wulpen komt evenwel nooit meer tot stand: het eiland Wulpen gaat inderdaad zijn totale ondergang tegemoet. Daarentegen overtreft het eiland Cadzand in 1415 voor de eerste maal zijn vroegere grootte, dank zij het terugwinnen van de oostelijke rand, gevormd door de Strijdersgatpolder. $\mathrm{Na}$ deze vaststellingen inzake de hoofdlijnen van de stormvloedgeschiedenis blijven nog biezonderheden betreffende de omvang van de ontstane schade te behandelen.

De verliezen geleden door Sint-Baafs op Cadzand en Wulpen, worden door getuige 6 nog door meer uitgebreide inlichtingen gespecifieerd, met name aangaande de verdeling van de schade over de twee eilanden. Getuige 4 had het gehouden op het verlies van het derde deel van alle tienden en landerijen op Cadzand, en op het verlies van bijna alle bezittingen en inkomsten van Sint-Baafs op Wulpen. Dit liet echter de vraag open naar de omvang van de schade in haar geheel, gemeten tegenover het vroegere bedrag van de inkomsten. Getuige 6 bezorgt ons die op summiere wijze voor het hele gebied met het gegeven dat zeker de helft van de inkomsten en opbrengsten verloren waren ("bene medietatem fructuum reddituum et emolumentorum... pervenire solitorum irrecuperabiliter amisit"). Hoe hij tot dit inzicht gekomen is, verklaart hij als volgt: Sint-Baafs inde in vier van de vijf parochies van het eiland Cadzand-Wulpen alleen alle tienden en bezat bovendien ook veel eigen grond in die parochies. Drie van deze parochies zijn intussen volledig verzwolgen en ook een groot gedeelte van de vierde parochie. Hetgeen hier overbleef moet de kleine hoewel ("parvula motula") met zijn armtierige nederzetting zijn geweest. Als nu de beoordeelaars van deze tekst in Doornik zich de konsekwenties met betrekking tot de opbrengsten van tienden en grondpachten proberen voor te stellen, komen zij er met een eenvoudige berekening gauw uit. Inderdaad, als zij gemakshalve de eventuele verschillen in opbrengst tussen de vier parochies buiten beschouwing laten, komen zij gewoon op een achtste deel uit, waarbij zij de helft van de vierde parochie als behouden beschouwen. Dit is ongeveer wat de voorstelling van de getuige suggereert, want zelf doet hij deze berekening niet voor.

Het resultaat voor Cadzand is niet zo katastrofaal. Hoe we dit moeten beoordelen, maakt ons getuige 6 duidelijk door te verwijzen naar het hem blijkbaar zeer vertrouwde systeem van tiendheffing door Sint-Baafs in de verschillende tiendomschrijvingen. De tiendopbrengsten van de abdij komen met name uit zeven dergelijke omschrijvingen, die uiteenlopende bedragen opbrengen. Hiervan zijn er nu twee met hoge opbrengsten volledig verloren 
gegaan, wellicht voorgoed. Indien wij nogmaals met eenvoudige berekeningen werken, komen we tot zowat twee zevenden voor het schadeverlies, wat dan op zijn beurt vijiwel exact beantwoordt aan het derde deel waarover getuige 4 het had. Eigenaardig genoeg echter is daarin niet begrepen het toch beslist grote verlies aan pachtinkomsten uit Cadzand. Maar al die gegevens zullen wel zo moeten worden verstaan, dat de toehoorder er kon uit afleiden, dat in ieder geval de reeds vaker vermelde helft werd bereikt. Wel wordt duidelijk gezegd dat de totale schade niet veroorzaakt werd door één enkele stormvloed, maar dat ze het resultaat is van alle in aanmerking komende overstromingen van de laatste $\mathbf{4 0}$ jaar ("...per predictas inundationes successive fuerint ac sint et remaneant irrecuperabiliter submersi").

De twee andere getuigen uit Cadzand bevestigen niet enkel wat hun voorganger al beweerd had, maar voegen er ook nog een of andere eigen opmerking aan toe. Zo zegt getuige 7, dat hij ergens in het verloop van de betrokken periode heeft vastgesteld dat het eiland Cadzand drie jaren na elkaar helemaal niets opbracht ("vidit infructuosam omnino") ${ }^{43}$.

Getuige 8 varieert op een interessante manier de beweringen van zijn streekgenoot. Hij neemt namelijk uitdrukkelijk niet diens formulering over betreffende de twee beste tiendomschrijvingen ("duo meliorum anguli"), doch houdt met nadruk vast aan zijn eigen formulering. Hij spreekt namelijk niet van tiendomschrijvingen ("anguli") maar van polders ("quod quatuor vel quinque polri in quibus ipsum monasterium ibidem decimas habebat omnino sunt submersi"). Dat hij hierdoor ook de schade anders zou berekenen, wordt niet gezegd en is ook niet waarschijnlijk. Duidelijk is wel, dat hij het niet over "anguli" wil hebben, gewoon omdat hij die niet kende. Om dezelfde reden kon hij dan natuurlijk ook niet de schatting van de schade op twee zevenden bevestigen, gezien ook die gebaseerd was op de bekendheid met de "anguli". Het getal van vier of vijf overstroomde polders waarover hij het heeft, is weliswaar geen bevestiging van wat getuige 6 had beweerd, maar het is er ook niet in tegenspraak mee. Wel moet worden aangenomen, dat de tiendopbrengsten in deze polders kunnen beantwoorden aan het geschatte derde en aan de geschatte twee zevenden. Voor het overige kan uit dit aantal helemaal niet worden afgeleid hoe uitgestrekt het overstroomd gebied wel kan geweest zijn. Wel moet men onder de "polri" van Cadzand de latere zogeheten 'beginnen' verstaan, doch de enorme verschillen in oppervlakte van deze beginnen onderling, laten geen berekeningen toe.

Hoewel de organisatie van de tiendheffing door Sint-Baafs niet het eigenlijke onderwerp van onze uiteenzetting vormt, willen wij hierop nochtans even ingaan voor zover wij door onze onderhavige tekst zelf daartoe gebracht 


\section{H. D. MEYER}

worden, en het verder over toestanden gaat waarmee onze getuigen te maken hebben gehad. Hoger hebben wij voetstoots aangenomen, dat met de vier parochies op het eiland Cadzand-Wulpen waarbinnen Sint-Baafs het alleenrecht op tiendheffing had, de vier parochies van Wulpen werden bedoeld. De talrijke eigen gronden ("multae terrae propriae") die de abdij daar ook nog zou bezeten hebben, laten we buiten beschouwing, want die zijn wellicht niet eens al te woordelijk te verstaan. Uit de expliciete opmerking van getuige dat Sint-Baafs in vier van de vijf parochies als enige alle tienden hief ("in quarum quinque parochiarum quatuor predictum monasterium solum omnes decimas ... habere solebat"), vloeit echter wel noodzakelijk voort dat dit voor de parochie Cadzand niet gold en dat dàa dus de tiendopbrengsten gedeeld moesten worden. Dit verschil tussen Cadzand en Wulpen is van belang omdat het wijst op toestanden waarvan getuige zelf zich niet bewust is geweest. Het kan immers zijn dat hij de bestaande toestand met toestanden die vroeger hadden bestaan heeft vermengd. Wij wijzen enkel op dit probleem, dat samenhangt met het gebruik van de uitdrukkingen "territorium de Cadsand" en "parochia". Omdat dit niet zonder lange omwegen kan worden toegelicht, gaan we er niet verder op in ${ }^{44}$. Trouwens, de geloofwaardigheid van de uitspraak over de omvang van de schade, hangt er geenszins van af. Wel moet worden ingegaan op het probleem van de "anguli".

Klaarblijkelijk vormen de "anguli" (= "hoek(en)") genoemde omschrijvingen de basis van de organisatie door Sint-Baafs van de tiendheffing op Cadzand. Getuige 6 leert ons over dit systeem het volgende: "op het grondgebied van Cadzand waar de tienden van de abdij over zeven hoeken waren verdeeld" ("in territorio de Cadsant ubi decime dicti monasterii per septem angulos dividi solebant..."). Het gaat dus over zeven tiendomschrijvingen, waarin het gezamenlijke aan de abdij tiendplichtige grondbezit op Cadzand onderverdeeld was. Dergelijk systeem is ook elders bekend, zodat niets belet aan te nemen dat hier zoals elders het korentiend normbepalend was. Het Latijnse "angulus" is de getrouwe vertaling van het Vlaamse "hoek", dat we vaak aantreffen als synoniem voor polder of voor begin ${ }^{45}$. Ook daar waar

44 Het probleem van de tienden op Cadzand-Wulpen is helemaal niet duidelijk De gegevens van vóór 1375 daarover zijn nog niet voldoende bestudeerd. Zo zijn er bijvoorbeeld ernstige aanwijzingen voor een heel ander tiendensysteem op Cadzand dan het hier te handhaven Siebense schema. Verder kunnen we evenmin zo maar uit de bronnen opmaken hoe het stond met de tiendrechten in de vier parochies op Wulpen.

45 Oudste aanduiding is "Bertenhuc" op Cadzand (Serrure, C.P., Cartulaire de Saint-Bavon d̀ Gand (655-1255), Gent, 1836, nr. 57. Te dateren tussen oktober 1178 en 1182, cf. Vleeschouwers, C., De oorkonden van de Sint-Baafsabdij te Gent (8191321). II. Uitgave, Brussel, 1990, nr.68), in de editie van de corkonden van Filips Van den Elzas door de Hemptinne Th. en Verhulst A. opgenomen onder het nr. 632 
"(h)oec" in de lijsten van tiendomschrijvingen opduikt, is het woord niet de technische term voor "tiendomschrijving", maar behoort gewoon tot de benaming van de polder waarmee de omschrijving samenvalt of waarin ze ligt. Dit wordt voldoende bewezen door het feit, dat in een lijst van tiendomschrijvingen menige tiendomschrijving wel zo wordt genoemd, maar lang niet allemaal. Juist dit moet op Cadzand anders geweest zijn. Als we de twee hoger behandelde getuigenissen met elkaar combineren, dan komen we tot het besluit, met betrekking tot zeven tiendomschrijvingen (anguli), dat de overstroming van minstens vier polders tot het verlies van twee omschrijvingen dit is twee zevenden leidde. Dit betekent dus dat twee "hoeken" ("anguli") zich over minstens vier polders uitstrekken. Dat is alvast voldoende om te bewijzen, dat in vele gevallen een tiend"hoek" zich over meer dan één polder uitstrekte, dit wil zeggen, dat hij een combinatie van polders moet zijn geweest. Maar ook de nog overblijvende rekenkundige mogelijkheid dat een tiendomschrijving toch nog eens.met een polder samenviel, kan voor Cadzand worden weerlegd. De polders op Cadzand zijn de later zogeheten beginnen. Ook al kennen we voor de periode vóór de grote stormvloeden en de nieuwe bedijkingen hun aantal nauwelijks of zelfs helemaal niet en ook al was hun oppervlakte, zoals reeds gezegd, zeer uiteenlopend, toch is het totaal uitgesloten dat één enkel begin, al was het maar van ver, één zevende van de totale oppervlakte zou hebben ingenomen en één zevende van de opbrengst zou hebben bereikt. Dit laat toe te besluiten dat alle "hoeken" ("anguli") verzamelingen van meerdere beginnen waren, waardoor men trachtte zowat één zevende van de opbrengst te bereiken. Omdat dit maar bij benadering ging, waren er "betere" hoeken ("anguli meliores") en "slechtere" ("anguli peiores"). Onder zulke omstandigheden kon evenwel nooit gebeuren op Cadzand wat elders vaak voorkwam en er zelfs algemene regel was, namelijk dat een polder over twee tiendomschrijvingen werd verdeeld ${ }^{46}$. Hieruit blijkt tevens hoe klein de beginnen wel waren.

Uit dit eigen karakter van de tiendomschrijvingen op Cadzand, volgt noodzakelijkerwijze nog een andere konsekwentie: ze konden niet eenvoudig met behulp van de naam van een bepaalde polder worden aangeduid, omdat een speciale relatie tot één bepaalde polder ontbrak. Men gebruikte de namen van de polders dus helemaal niet, maar wel een of andere aanduiding gevolgd door het achtervoegsel -hoek. Gegevens uit dokumenten van SintBaafs zelf bevestigen dit. Zo vinden we in een lijst van onvereffende betalingen - die bij vereffening telkens worden doorgehaald - vermeld: "van tienden van den middelhoucke", "van tienden van den driehoucken" en "van

(in voorbereiding). Later heten heel wat beginnen op Cadzand zo, eveneens meerdere polders in het Ambacht Ijzendijke. Verg. Gottschalk HG1, 22, 108, 157 vgl.; 165.

46 Bv. Zuut Hughevliete of Noord Hughevliete. 


\section{H. D. MEYER}

tienden van den boesthoucke"; telkens betaalt er een andere persoon op die posten ${ }^{47}$. Hoe karig deze gereconstrueerde gegevens omtrent de organisatie van de tienden, zoals Sint-Baafs die op Cadzand had ingericht, ook mogen zijn, toch moeten wij er dankbaar om zijn bij gebrek aan betere overleveringen. Overigens kan men ook niet meer inlichtingen verwachten van een getuige, die immers geenszins als ambtenaar met deze aangelegenheden te maken had, doch die gewoon als inwoner van Cadzand laat horen op de hoogte te zijn van streek en volk.

\section{c. Weert en Altena}

De Sint-Baafsabdij moet de schade veroorzaakt te Weert dermate als model hebben gezien, dat ze daarvoor een speciale getuige ${ }^{48}$ liet komen, en daarbij ook nog twee andere getuigen om zijn uitspraken te bevestigen. Tevoren hadden trouwens al drie andere getuigen het onderwerp behandeld, en één van hen had dit zelfs vrij uitvoerig gedaan ${ }^{49}$. We hebben er reeds op gewezen, dat die hoofdgetuige ongewoon uitgebreid verslag had uitgebracht. Die indruk wordt vooral gewekt door de gedetailleerde behandeling van de technische gegevens, waardoor de toehoorders die ondeskundig waren qua waterbouwkunde, ten minste in zoverre op de hoogte werden gebracht, dat ze in staat zouden zijn de problemen om speciaal een riviereiland tegen wateroverlast te beschermen, ook werkelijk te begrijpen en te beoordelen. Klaarblijkelijk bestond de vrees, dat deze overstromingen zouden kunnen worden onderschat tegenover de stormvloeden aan de zeekust. Welke overigens de samenhang van de rivieroverstroming bij Weert met de stormvloedoverstromingen aan de kust is geweest, wordt nergens gezegd, doch steeds als vaststaand beschouwd.

Het eiland Weert, dat in de gemeente Temse ligt, wordt volgens het bericht van de deskundige, volledig omsloten door Schelde en Durme ("circumcincta decursibus duorum fluviorum licet Schalde et Deurme") ${ }^{50}$.

$47 R 83 / 10$ van $1399 / 1400$.

48 Getuige 17-fol. 21v; 22r.

49 Getuige 2-fol. 5r; getuige 1-fol. 3r; getuige 5-fol. 10v.

50 Vgl. ook Vleeschouwers, De oorkonden, nrs. 259 en 260 van 1241:"... totam illam terram ...Scalde vel Dorme aqua undique interclusam ..."; Verhulst, Grondbezit 579. Deze plaatsbeschrijving veronderstelt dus dat de Durme verder oostelijk in de Schelde uitmondde dan thans en dat de huidige loop van de Schelde de vroegere benedenloop van de Durme is geweest. De dijk van Weert (of van de twee Weert's) bestond dus uit een Scheldedijk en een Durmedijk; vgl. R57 fol 12v van 1363: "super dicum propinquum Dorme vel Schalde...". In rekening K 9318 (fol. 3r van 1387/88) vinden we eveneens leerzame details: "Weert valet cum decimis et octo solidis gr. reddituum in Thamisia defalcatis 23s.gr. pro terris in quibus novus dikus est positus 100lb. 12s. 1d. gr. 69 capones et unum modium avene". Wat voor onbekende inkomsten uit Temse dat waren, vernemen we hier niet. Het was blijkbaar de nieuwe dijk die grote kosten vereiste: "item pro dicagiis $25 \mathrm{lb} 13 \mathrm{~s} 2 \mathrm{~d}$ gr. 6 mitas". Maar 


\section{NIEUWE GETUIGENISSEN OVER STORMVLOEDSCHADE IN Z-V}

Het heeft altijd in zijn geheel tot het bezit van Sint-Baafs behoord. Daarom staat alléén de abdij voor alles in, zowel voor beslissingen over.de noodzakelijke werkzaamheden als over de uitvoering en de financiering ervan. Hier wordt vooral de aandacht gevestigd op het feit dat alle werken in verband met de ligging in de rivier, erg omslachtig en daardoor ook erg duur uitvallen. De dijkaanleg in beperkte zin is dan nog het voordeligst in prijs. Daarnaast zijn er dan nog die beveiligingswerken, die de vertaler niet heeft kunnen of willen vertalen in het Latijn, en waarvoor hij dus gewoon de Vlaamse benamingen heeft aangehouden, namelijk "vulgariter weeren vel hoofde", - ze dienen dus tot bescherming tegen de stroming. Vooral de inspanning die moet worden geleverd wordt onderstreept, aangezien die werken in (stromend) water moeten uitgevoerd worden ("ex fundo... fluviorum sumptuose...", of ook "intra aquam sumptuose...factis").

De meeste moeite echter kosten wel de sluiswerken - "sumptuosissime" worden ze genoemd -, die dan ook het voornaamste onderwerp van de uiteenzetting vormen. Blijkbaar omdat men weer onkunde van leken in deze aangelegenheid vreest, wordt er op geattendeerd dat sluiswerken niet enkel in samenhang met bedijking of dijkherstellingen worden uitgevoerd, maar ook dat sluizen zeer kwetsbaar zijn en vaker beschadigd dan dijken ("etiam sepius extra et ante dictos a $\left.(g) g e r e s^{\prime \prime}\right)$. Door een en ander zijn de sluizen dan ook de duurste voorzieningen van alle beschermingswerken op het eiland.

Om dit alles te dokumenteren werkt getuige 17 een rekening uit die de vergelijkingen duidelijk laat zien. Hierin heeft hij de "ordinaria onera", waaronder hij de onderhoudskosten van alle waterbouwwerken verstaat, bij de herstellingen aan de sluizen opgeteld, waardoor hij tot de volgende balans komt: de pacht uit het gehele eiland brengt voor de abdij per jaar $90 \mathrm{lb}$.gr. op, waarvan ze echter voor de genoemde uitgaven $50 \mathrm{lb}$. gr. afstaat. Ze heeft aldus - en dit is het waar getuige naar toe wil, om naar het belangrijke sleutelgetal te kunnen verwijzen meer dan de helft van haar normale inkomsten uit Weert "ultra consuetam medietatem" ingeboet. Desondanks is deze berekening toch nog misleidend, want ze geldt enkel bij normale toestanden. Er zijn evenwel steeds opnieuw jaren tijdens dewelke de totale opbrengst van Weert niet eens genoeg is voor de beveiliging tegen het water. Vooral één beslissende factor mag niet over het hoofd worden gezien: het herstel van de waterschade kan nooit worden uitgesteld of verschoven, het moet aanstonds gebeuren ("cum inundationibus huiusmodi quando accidunt subito resistere oporteat"), anders verlaten de bewoners het eiland onmiddellijk. Zulke uitwijking van de bevolking betekent evenwel dat het

hoogstmerkwaardig is dan wel weer, dat de kosten voor de herstellingen aan de sluizen die ook groot waren niet geboekt worden onder de "dicagia", maar dat ze als een aparte post worden vermeld: "item pro sclusis et goteriis reparandis cum lignis emptis $12 l b$ \&s gr.". 


\section{H. D. MEYER}

eiland onbewoonbaar wordt en derhalve geen ekonomische waarde meer bezit ("et sic dicta insula remaneret inhabitabilis et nullius valitatis et omnino deperdita"). Een en ander verwijst dus naar de noodzaak in dergelijk geval meteen het benodigde geld voor te schieten en niet op de rendabiliteit te letten.

Hiermee is het nare tema van de dure sluiswerken nog niet uitgeput. Getuige neemt precies de noodlottige situatie van het ogenblik te baat, om een indruk te geven, in absolute cijfers, van de financiële druk die de bouw van een nieuwe sluis, meebrengt. In dit jaar 1411 werd een nieuwe sluis gemaakt, die het klooster 110 lb.gr. heeft gekost. In het jaar 1412 moeten er weer nieuwe werken uitgevoerd worden. Het is namelijk zo, heet het in een niet zo geslaagde formulering, dat de ondergrond van het eiland steeds meer verslechtert ("fundus dicte insule...deterioratur"), waardoor de dijken hun fundering verliezen ("aggeres evelluntur"). Dat veroorzaakt nieuwe stijgingen van de onkosten. In ieder geval blijkt uit een op deze feiten gebaseerde berekening, die al gemaakt is en die door getuige korrekt wordt verklaard, dat Sint-Baafs in de komende vier jaar geen opbrengst van het eiland Weert zal ontvangen. Immers, de bouw van een nieuwe sluis slokt alvast de opbrengst op van twee jaar, die, na aftrek van de vermelde gewone en buitengewone uitgaven, nog overblijft. Ook getuige 5 verklaart dit ${ }^{51}$, die met een berekening over twee jaren aankomt en uitlegt dat de abdij door herstellingen en vernieuwingen de opbrengst van deze twee komende jaren nu al geheel heeft uitgegeven ("fructus et proventus de dictis bonis infra biennium profuturi" ${ }^{\prime \prime}$. De tweede vernieuwing dient dan met inkomsten uit het derde en vierde jaar gefinancierd te worden.

De bezittingen in Altena, waarover slechts éénmaal sprake is in ons dokument, vormen een speciaal geval waarbij enkele toelichtingen nodig zijn. Eerst en vooral was het tot nu toe onbekend dat ook deze grote hoeve van Sint-Baafs dermate door de overstroming bedreigd was, dat ze wegens de hoge onkosten niet meer winstgevend kon geëxploiteerd worden. Verloren land wordt evenwel niet gesignaleerd, en mag dan ook worden uitgesloten. Nochtans zijn de uitgaven voor de bescherming en redding van zekere gronden te Altena of ertoe behorend ("pro defensione et salvatione cuiusdam possessionis locate Altena et terrarum ad eam pertinentium") vaak - dus niet altijd - zodanig hoog, dat de opbrengst erdoor wordt opgeslokt. In verband hiermee vertelt getuige 10 , dat hij van de huidige abt gehoord heeft, dat hij deze hoeve, kompleet met alle aanhorigheden, het liefst zou willen opgeven, indien hij dit met een gerust geweten kon doen ("si hoc salva sua conscientia facere posset"). Wat hier speciaal over Altena wordt beweerd, wordt door andere getuigen in meer algemene zin op alle verlieslatende bezittingen

51 Fol. 10v. 


\section{NIEUWE GETUIGENISSEN OVER STORMVLOEDSCHADE IN Z-V}

betrokken. Getuige 14 heeft het over ettelijke analoge gevallen in de Ambachten Aardenburg en Oostburg, en beweert van de abt vernomen te hebben dat hij ook van deze gronden liever zou afgeraken ("huiusmodi dampnosas terras libenter dimitteret"). Getuige 3 van zijn kant verwijst naar abt Walter en diens opvolger-in-funktie, alsook naar andere geestelijken. Hij schrijft hun een onduidelijk geformuleerde verklaring toe, waaruit moet blijken dat zij er niets op tegen zouden hebben, moesten er nog méér dan tot nu toe het geval was geweest, van de verlieslatende bezittingen verloren gegaan zijn, en dat ze zelfs van die landgoederen, die jammer genoeg behouden waren, er graag nog wel enkele wilden opgeven ("plures predictarum terrarum libenter dimisissent"). Tenslotte bericht getuige 5 over de vele dergelijke bezittingen bij de zee ("plures huiusmodi terre iuxta mare iacentes"), die de abt wel zou willen afstoten, als hij - zoals geen enkele getuige nalaat te verklaren ! - daardoor zijn geweten niet zou bezwaren. Het is trouwens ook deze getuige die als enige vermeldt, dat de abt bij dit alles de bedoeling had de pauselijke toestemming tot het opgeven van landeigendom aan te vragen. Overigens staat dit ook aangekondigd in de mededeling van Sint-Baafs aan de kommissaris voor de tienden van het bisdom Doornik ${ }^{\mathbf{5 2}}$. Er kan dus geen twijfel bestaan aangaande de juistheid van dit bericht. De versies van verschillende getuigen bewijzen dat die intentie herhaalde malen en bij menige gelegenheid uitgesproken is. Bijgevolg is het duidelijk dat de Sint-Baafsabdij in de noodsituatie, waarin ze door grote, maar niet totaal vernielende overstromingen van haar landerijen was geraakt, ernstig overwogen heeft haar gevaarlijk gelegen bezittingen langs de kust, die gevaar liepen, op te geven. $\mathrm{Ze}$ was immers bestendig bevreesd dat haar niet rendabele uitgaven haar vermogen zouden gaan aantasten. Onmiskenbaar ligt er een zekere paradox in het feit, dat uitgerekend het niet volledig geruineerde land het grootste gevaar voor de abdijfinancies vormde.

Voor zover we weten is die vertwijfelde stap nooit gezet. De hindernissen die dit tegenhielden moeten slechts zeer moeilijk te overwinnen zijn geweest. Te bedenken valt hierbij dat het ging om het opgeven van grondbezit, wat geenszins te vergelijken is met de vaak voorkomende weigering deel te nemen aan een herbedijking. In dit laatste geval ging het om land dat al verloren was en dat men meestal aan iemand overliet, die voordeel zag in een herbedijking. In het andere geval daarentegen zou het besluit niets meer te investeren, betekend hebben, dat weliswaar bedreigde doch op het ogenblik van de beslissing nog geëxploiteerde landbouwgrond, zo maar aan de zee zouden prijs zijn gegeven. Hier lag de drempel die men niet overschreed, afgezien van het kerkrechtelijke aspekt.

52 Fol. 1r. 


\section{H. D. MEYER}

\section{d. De Vier Ambachter.}

De hoogbejaarde getuige nr. 1, Van den Bossche (de Busco), geeft geen nadere inlichtingen over de schade in de Vier Ambachten. Dit is des te opvallender omdat hij, naar eigen zeggen, juist dààr gevolmachtigde van Sint-Baafs voor het dijkbeheer was geweest.

Getuige $5^{\mathbf{5 3}}$ daarentegen raamt de schade aldaar, zonder in details te treden, aan de hand van twee relatieve getallen: de inkomsten zijn verminderd tot de helft van het bedrag vóór bedoelde overstroming ("bene ad medietatem illius quod ante predictam submersionem valere solebant diminuti"), terwijl de uitgaven alleen al voor de bedijkingswerken - zoals hij uit de abdijrekeningen heeft kunnen opmaken - gestegen zijn van minder dan één groot Vlaams per gemet tot vijf groten.

Zoals reeds eerder aangestipt, komt de manier waarop de eveneens hoogbedaagde getuige $16^{54}$ Jan Rascaert zijn uitspraak formuleert zeer eigenaardig over. We begrijpen niet, waarom hij de naam van de destijds door hem gepachte hoeve Vogeldijk niet noemt. Wat hij opgeeft aan preciese cijfers kan jammer genoeg niet met andere vergeleken worden. Naar zijn zeggen heeft de overstroming een schade aangericht van wel duizend Franse kronen ("bene mille coronarum Francie in partibus tunc submersis"). Dat de hoeve zelf toen niet werd verwoest, blijkt hieruit en is ook zondermeer duidelijk. Er is geen enkele aanduiding hoe hij die berekening heeft gemaakt en zeker niet of in de eindsom gederfde inkomsten en onkosten voor wederingebruikneming inbegrepen waren. Bovendien heeft hij het uitsluitend over de schade die hij zelf als pachter heeft geleden. Daaruit te concluderen tot de schade die Sint-Baafs heeft geleden, is bijgevolg niet mogelijk.

Getuige 3 is de eigenlijke zegsman voor de Vier Ambachten, die de meeste gegevens over de plaatselijke omstandigheden en over de omvang van de door de abdij geleden verliezen kan leveren. Zijn informaties over Biervliet en omgeving staan daarnaast op zichzelf en moeten nog apart worden besproken. Hij is de enige die uitstekend op de hoogte is inzake de oostelijke gebieden van de Vier Ambachten en juist daarover de meest preciese cijfers uit heel zijn verslag weet te verstrekken. Er kan echter geen onderscheid worden gemaakt in zijn getuigenis tussen de stormvloeden van 1375 en van 1404, noch tussen de gebeurtenissen die zich hebben voorgedaan tussen die twee data. Er wordt door deze getuige zo onontwarbaar gesproken over stormvloeden en overstromingen, zowel in het meervoud als in het enkelvoud en in eén en dezelfde zin, dat men al die verhalen beter beschouwt als een resumé van de toestand nà 1404 .

Voor het overige heeft de abdij in de Vier Ambachten ook verder nog jaarlijks verliezen te betreuren tegenover de vroegere inkomsten aldaar,

53 Fol. 10v.

54 Fol. 19r. 
omdat de pachtsom voor de overgebleven landerijen niet meer de pachtbedragen per gemet van eertijds bereiken. Van de pachtgoederen in de parochies Perbome, Steeland, Hertinge en Willemskerke wordt gezegd dat ze gemiddeld nog slechts 12 groten per gemet opbrengen, behalve enkele van de beste gronden ("exceptis paucis de melioribus terris"), die nog 30 groten per gemet betalen. Vroeger had men daar tot 40 groten per gemet kunnen vragen. Zeer opmerkelijk is hetgeen de getuige over de parochie Ossenisse zegt. Hij betrekt hier in het bedrag der inkomsten nu eens niet, zoals dat nochtans altijd het geval is geweest, de opbrengst van vòòr de eerste overstroming van 1375, maar heeft nù al meteen met de ondergang van talrijke goederen der abdij rekening gehouden. Hij vergelijkt thans de som van $38 \mathrm{lb}$.gr., die ook nog gedurende enkele jaren na deze overstroming binnenkwam, met de 21 lb.gr. waarmee Sint-Baafs het nu moet stellen. In dit geval is dus rekening gehouden met alle maar denkbare oorzaken van landverlies en van waardevermindering van de grond. Het is het enige geval, waarin we tenminste voor één welbepaalde streek aan de cijfers een houvast hebben, waaruit we kunnen opmaken, hoe hoog de schade aan het na 1375 overgebleven land nog kon oplopen. Voor Ossenisse komt dit op amper twee vijfden. Deze gegevens verplichten er ons overigens toe, de tot heden gerechtvaardigde opvatting als zou de stormvloed van 1375 geen merkbare invloed in Ossenisse ${ }^{55}$ hebben gehad, te herzien.

De voorstelling van de situatie in de parochies Adendijk en Otene is eveneens met geleden verliezen en uitgaven gestoffeerd. Hier zijn vooral nieuwe dijken nodig, klaarblijkelijk inlaagdijken want de aanleg ervan om het buitenwater te keren en om groter onheil te voorkomen ("ad fugiendum mare et maius dampnum vitandum") gaat gepaard met het prijsgeven van land buiten deze inlaagdijken ("plures terras extra huiusmodi aggeres mari relinquere").

Op basis van al deze door hem meegedeelde feiten, waagt getuige het een globale raming van het verlies aan inkomsten voor de Sint-Baafsabdij in de Vier Ambachten te maken. Hij onderstreept daarbij zijn goede bedoeling de schatting niet te hoog te maken ("nolens ut dicit nimis dicere"). Volgens hem zijn de inkomsten zonder rekening te houden met de vermelde bedijkingskosten sedert de eerste overstroming gedaald tot minder dan het derde van vroeger ("ad minus in tertia parte post dictam submersionem"). Ook voor de Vier Ambachten belanden we dus bij een schadeomvang waarmee we al vertrouwd zijn.

55 Fol. 7 v; vgl. Gottschalk, Vier Ambachten 315; vgl. verder blz. 38 onderaan. 


\section{H. D. MEYER}

\section{e. Biervliet en ruimere omgeving.}

Wij behandelen dit gebied apart, buiten het kader van het ambacht waartoe het behoort. Ten eerste, omdat één van de getuigen er speciale inlichtingen over verstrekt. Ten tweede, omdat we ons genoopt zien hier iets uitvoeriger te zijn hetgeen ertoe moet bijdragen de details van de katastrofe van 1375 en haar voorgeschiedenis te verduidelijken.

Getuige $4^{56}$, die uit zijn eigen herinneringen put, heeft het eerst en vooral met de gewenste duidelijkheid over de hoofdgebeurtenis van 1375, waaruit alle volgende zijn voortgekomen, namelijk de doorbraak, het zgn. "gat" (foramen) bij Biervliet: ("de illa magna et lamentabili inundatione maris que fuit XXXVI vel XXXVII annis vel circiter elapsis et quod per eam mare illud dampnosum foramen nunc dictum foramen de Biervliet fecit..."). Ongeveer in dezelfde bewoordingen drukt zich getuige $3^{57}$ uit: hij ook zegt immers dat de stormvloed van 1375 het nu zogeheten gat ("foramen") van Biervliet heeft doen ontstaan. Daarbij komt dan nog een verklaring van getuige 4, die we vooraf dienen op te helderen. Hij zegt namelijk, als hij uitweidt over de enorme uitgaven die Sint-Baafs heeft gedaan voor de bedijking en de wederbedijking, dat het grootste deel van dat geld, dat met groot risico bezorgd werd, volledig nutteloos ("penitus inutiliter") werd uitgegeven door abt Johannes, de voorganger van abt Walter, vóór de grote overstroming en met het doel het "gat" van Biervliet te dichten ("nam ipsemet testis ut dicit vidit et audivit quod dominus Johannes dicti monasteriii abbas predecessor videlicet predicti domini Walteri pro obstruendo supradictum foramen de Biervliet plures magnas pecuniarum summas ante supradictam magnam inundationem exposuit quas omnes perdidit..."). Door deze besliste verklaring van een ooggetuige staat de datering volmaakt vast. Het is dan ook geraden in dit opzicht konsekwent te zijn en de vaak verdedigde opvatting op te geven als zou de overstroming van 1377, waarvan de gevolgen voor andere streken van Vlaanderen weliswaar vaak zijn onderschat, ook zekere gevolgen zou hebben gehad voor het Gat van Biervliet ${ }^{58}$. Er moet dus terdege nota worden genomen van het tot nog toe onbekende feit dat abt Johannes (III) (1352-1394) van de Sint-Baafsabdij, reeds yóór de stormvloed van 1375, dure doch mislukte pogingen had ondernomen om het "gat". van Biervliet af te dammen. Het is van belang dieper op deze aangelegenheid in te gaan met het oog op de betekenis van de overstroming van 1375 en om nog bestaande onduidelijkheden in verband hiermee uit de weg te ruimen.

56 Fol. 8v,

57 Fol. 9v.

58 Gottschalks vroegere opvatting op dit punt (Stormvloeden en rivieroverstromingen 1,1971 , pp. 431, 456 vlg.) schijnt mij juister te zijn dan haar latere (Vier Ambachten 299). 


\section{NIEUWE GETUIGENISSEN OVER STORMVLOEDSCHADE IN Z-V}

Eerst en vooral moet de schijnbare tegenspraak worden verklaard, dat er al vóór de doorbraak van 1375 aan de afdamming van het "gat" zou zijn gewerkt, terwijl deze bres pas geslagen is bij die doorbraak. Het gaat hier blijkbaar slechts over een gemakkelijk te begrijpen taalkundige onnauwkeurigheid. Hier wordt met "foramen de Biervliet" natuurlijk bedoeld, "de plaats, waar later het zogenaamde Gat van Biervliet ontstond". Maar hiermee wordt nu juist het probleem zakelijk gesteld: wat was er af te dammen ("obstruere"), als de doorbraak nog helemaal niet was gebeurd ? Hierop kan na alles wat we over de toestand binnen dit gebied weten, met grote stelligheid geantwoord worden, vooropgesteld dat we degelijk rekening houden met alle desbetreffende aanknopingspunten.

De kuststrook aan de zuidelijke oever van de Honte ${ }^{59}$ werd door een hele rij van kleine waterloopjes onderbroken. Getuige daarvan zijn de vele benamingen eindigend op -vliet, zoals bijvoorbeeld ook Biervliet. Langs de oevers van die riviertjes lagen doorgaans dijken en ingepolderd land, dat men zeker ook poogde uit te breiden. Bij gebrek aan bronnen kennen we daarover geen details. Vandaar dat ook niet te bewijzen valt of er al pogingen waren geweest om die vlieten af te dammen, wat echter wel waarschijnlijk is. Hoe dan ook, die waterlopen moet men van ons standpunt uit in ieder geval als zwakke plekken zien, die bij stormvloed risico's boden, hoofdzakelijk als de wind uit het noorden kwam.

Dit geldt meer bepaald voor het gebied ten noordoosten van Biervliet, wegens de speciale fysische gesteldheid aldaar. In de omgeving van de plaats waar vroeger de eigenlijke Biervliet uitmondde in de Honte en waar later de toegang tot de haven van het plaatsje Biervliet lag, moet het sinds lang tot sterke oeverafschuivingen gekomen zijn. Of zulks echter alleen bij hoge waterstanden, of ook bij normaal tij gebeurde, weten we niet. In ieder geval was dit verschijnsel zo karakteristiek, dat men die plaats "Breckeme" d.w.z. "breek" - of brokkelplaats noemde. Deze naam werd uiteindelijk zowel gebruikt voor de ontstane inham als voor het water, dat eertijds de benaming Biervliet had gedragen.

Aangenomen mag worden dat de benedenloop van deze Bier-"vliet" waar in de dertiende eeuw nog de naam Biervlietermuden voorkomt, die nadien verdwijnt 60 - evenzeer onder oeverschuivingen heeft geleden en misschien zelfs aan de oorsprong van het fenomeen heeft gelegen. De benaming Biervliet sloeg dan enkel nog op de bovenloop van de rivier, die steeds korter werd, en tenslotte nog maar alleen op de nederzetting die zich daar bevond. Het zou niet ongewoon zijn zo de haven van die nederzetting al vroeg een sluis had bezeten. Er is er stellig een geweest niet ver van Biervliet, aan het

59 Daarover Verhulst, Grondbezit 478 vgl.; Gottschalk HG1 $87 f$ vgl.; Vier Ambachten, passim.

60 Gottschalk, Vier Ambachten 53, 54, 101. 


\section{H. D. MEYER}

einde van het afwateringskanaal dat de "grote watergang" wordt genoemd en dat van Boekhoute kwam. Bovendien moet er nog op zijn minst een tweede kanaal zijn geweest, dat in de nabijheid van Biervliet eindigde. Deze "Biervlietse vaart" kwam uit Zelzate, doch zal geen eigen sluis hebben gehad, maar kan in het kanaal van Boekhoute uitgemond hebben ${ }^{61}$. Aan de rand van deze "Breckeme", in de parochies Boterzande en Wevelswale, lagen polders waar de abdijen van Sint-Baafs en Sint-Pieters aanzienlijk landbezit hadden. Een groot deel daarvan lag, volgens de oorkonden, vóór de dijken, alsook aan de oever van de Breckeme ${ }^{62}$. De twee abdijen hadden daar ook elk een eigen hoeve ingericht: Sint-Baafs die van Wevelswale, Sint-Pieters die ten oosten daarvan, bekend onder de naam "van den Zwarten Vliete", waardoor meteen haar ligging aan of nabij één van de vermelde waterlopen is aangeduid. Tot de westelijke oever van die vliet reikte ook een grondstuk van Sint-Baafs, en een ander grensde dan weer aan een water met de naam Hosingvliet.

De situatie, zoals hier geschetst, laat uitschijnen dat Sint-Baafs in deze polders een van de hoofdverantwoordelijken voor de bouw en het onderhoud van de dijken is geweest. Er moet rekening mee worden gehouden dat dergelijke grootgrondbezitters een zware verantwoordelijkheid te dragen hadden, daar hun invloed zich op het hele dijkwezen moet hebben doen gelden.

De situatie in het binnenland werd bepaald door de gevolgen van de turfwinning in de veengebieden. Zoals het afgraven van de turf de voorwaarden heeft geschapen voor de vorming van de Zuidzee, nadat eenmaal de doorbraak van het water was gebeurd, zo is misschien zelfs deze doorbraak zelf het gevolg geweest van de afgraving van de turf. Details over het turfsteken nabij de kust, hoewel zeldzamer dan voor het binnenland, laten zien dat turf ook werd gewonnen in Wevelswale, op gronden van Sint-Baafs, dus tot vlakbij de kust ${ }^{63}$. Het graven van turf is er ongetwijfeld mee de schuld van dat de drempel, die het water had te doorbreken en die het in 1375 ook inderdaad heeft doorbroken om verder geen enkele hinder meer te ondervinden, steeds smaller is geworden. De streek van BiervlietBoterzande-Wevelswale is dus een biezonder gevaarlijke zone geweest. De oeverafschuivingen aan de Breckeme en de turfwinning ten zuiden ervan versterkten elkaars fatale konsekwenties. Daar komt nog bij dat vlieten en kanalen zelf al doorbrekingen van de beschuttende oeverdammen vormden, terwijl hun sluizen biezonder gevaarlijke plaatsen waren. Met dit alles voor ogen, komt het er niet erg op aan of de inham van de Breckeme - want van een inham mogen we hier wel spreken - die we voor het eerst in 1360 met de

\footnotetext{
61 Gottschalk, Vier Ambachten 170, 183, 197, 221.

62 Vgl. hoger $\mathrm{n} .60$.

63 Gottschalk, Vier Ambachten 131.
} 


\section{NIEUWE GETUIGENISSEN OVER STORMVLOEDSCHADE IN Z-V}

meer moderne vorm "Brackeman" aantreffen ${ }^{64}$, meer of minder groot was. Veel belangrijker is de vraag hoe diep hij in het binnenland doordrong en beslissend bleef de vraag hoe smal de drempel was geworden. Hij hoefde niet over een grote lengte verdwenen te zijn, want een smalle doch diepe geul was genoeg om hoogst gevaarlijk te zijn.

$\mathrm{Al}$ ontbreken speciale getuigenissen over de toenemende oeverafschuiving aan de Breckeme, dan hebben we toch genoeg precieze informatie over herhaalde landverliezen door stormvloeden in deze streek ${ }^{65}$. Van tijd tot tijd had men zelfs op sommige plaatsen al het nieuw gewonnen land verloren en was men naar de oude dijken teruggedrongen ${ }^{66}$.

In deze gang van zaken moeten nu de bijzonderheden van de verschillende getuigenissen worden ingepast. Eerst en vooral moeten we trachten te begrijpen, hoe een getuige kan komen verklaren dat abt Johannes al lang vóór de erge overstroming (van 1375) zulke grote bedragen had uitgegeven om het gat van Biervliet te dichten ("pro obstruendo supradictum foramen de Biervliet"). Dit houdt in en doet veronderstellen dat kenners en inwoners van de streek er zich van bewust waren dat het gevaar niet zozeer een uitgestrekt dijkfront betrof maar een beperkte, welbepaalde plaats, in casu het "gat" van Biervliet, waarop men dan ook terecht de inspanningen koncentreerde. Alleen zó wordt verklaarbaar waarom de getuige het zo uitdrukkelijk heeft over de afdamming van het gat van Biervliet en niet gewoon over de geweldige uitgaven voor de bescherming van de kust, die Sint-Baafs in de polders waar de abdij grond bezat, moest doen. De plaats waar het gevaar dreigde moet dus zeer duidelijk herkenbaar en begrensd zijn geweest. Ze was gelegen aan het doorbraakpunt bij Wevelswale, dat waarschijnlijk ongeveer op de plaats van het latere Gat van Biervliet moet worden gesitueerd.

Terwijl deze uitdrukking in de tijd vóór 1375 een soort terreinverhoging aanduidde, kon men ook - zoals bijvoorbeeld in een getuigenis van 143967 . van bepaalde inkomsten van Wevelswale spreken "die verdronken en verloren zin in de zee als tgat van Biervliet huut ghinc". Dit betekent niet "het gat van Biervliet ontstond als waterdoorgang", maar wel "het gat van Biervliet ging in het water onder". Deze interpretatie wordt ook bewezen door het gebruik van het werkwoord "huut ghinc", zoals we dit weervinden in de bekende vermelding over de rampzalige nacht van 1375 in Saaftinge "als tland ute ghinc". Maar details over de genomen maatregelen, waarvoor

64 Gottschalk HG1 152.

65 Ondanks de stellingen terzake van Gottschalk (Vier Ambachten 27 vlg., 51 vlg., 227 vlg., 298) is hierover toch nog diepgaander onderzoek nodig, hetgeen hier echter niet mogelijk is. De getuigenissen zijn minder ondubbelzinnig dan we dachten.

66 Vgl. bv. Gottschalk, Vier Ambachten 52 vlg.

67 R45 fol 17v; vgl. ook Gottschalk, Vier Ambachten 296 vlg. De later voorkomende uitdrukking "brac inne" e.d. (Kroniek van Axel ed. de Mul blz. 62; Excellente cronike van Vanderen fol 65v) is minder ondubbelzinnig. 


\section{H. D. MEYER}

de door getuige vermelde grote sommen geld gebruikt werden, ontbreken in de overlevering, hoewel ze uiteraard voor de hand liggen: met name versterking van de dijken op de kritieke plaats en onmiddellijk herstel van alle schade, die zeker ook juist hier bij de diverse vermelde overstromingen ontstaan was. Toch blijft het verder opvallen, hoe de getuige deze inspanning alsook de financiering ervan uitsluitend op het aktief van de abdij schrijft. Zijn woorden komen zo over alsof de abdij alles alleen had opgeknapt. Zelfs als men geneigd is daarin een zekere overdrijving van de rol van Sint-Baafs te zien, omdat men immers aanneemt dat alle gelanden van de getroffen polders evenzeer verantwoordelijk waren en deel hebben genomen aan de werken, dan toch moet men aannemen dat de abdij, ten aanzien van de plaats waar de doorbraak later gebeurde, een bijzondere aansprakelijkheid en verantwoordelijkheid bezat. Het ligt voor de hand hierbij te denken aan reële bevoegdheden, waarover trouwens getuigenissen bestaan. De abdij kan echter ook zonder meer een aktieve rol hebben vervuld ${ }^{68}$.

Een aanduiding over de belangrijke plaats die de abdij als grootgrondbezitster innam, meer bepaald in het gebied van de overstromingsramp, krijgen we door een dokument daterend van kort na de overstroming. SintBaafs nam toen, volgens de rekening van het hof van Vogeldijk, maatregelen om het verloren.land terug te winnen, namelijk 500 gemeten (222 ha.) grond die vroeger tot het hof van Wevelswale hadden behoord. De abdij liet tien arbeiders een maand lang werken en betaalde hen. Hierbij is er geen sprake van dat iemand anders aan die onderneming deelnam of er medezeggenschap in had. Wat nu echter de diverse grote geldsommen betreft waarvan sprake in het getuigenis: ("plures magnas pecuniarum summas") : het zou ons te ver voeren de eventuele sporen ervan in de rekeningen van Sint-Baafs na te speuren ${ }^{69}$.

Het getuigenis bevat tenslotte nog iets merkwaardigs, dat tot verdere bedenkingen leidt. Het luidt met name over het ongelukkige verloop van het projekt in zijn geheel en over het verlies van het geld "dat alles verloren ging omdat het gat niet kon worden gedicht en het nog steeds niet is, omdat het wegens de diepte en de aanhoudende kracht van de overstromingen van de zee nooit zal kunnen gedicht worden, tenzij door een mirakel" ("...quas omnes perdidit quia foramen illud tunc obstrui non potuit neque adhuc obstructu(m) est nec umquam nisi miraculose obstrui poterit propter

68 Een voorbeeld dat op St.-Baafs slaat met betrekking tot de sterke invloed van machtige grondbezitters, is het optreden van de abdij in de polder van Oud Otene. Ze verwerpt daar de eis van de pachters, die naar een inlaagdijk vroegen en tegelijk ook naar de versterking van de oude dijk, als klaarblijkelijk overdreven. In de bijeenkomst met de grondbezitters verhindert de abdij de beslissing tot het bouwen van die dijk (K 2308 in 1408-1412).

69 Vgl. boven n. 66. 


\section{NIEUWE GETUIGENISSEN OVER STORMVLOEDSCHADE IN Z-V}

\section{inundationum maritimarum nimiam profunditatem et impetuositatem continuam").}

Dit wordt met een nadruk gezegd die helemaal niet past bij een zakelijk getuigenis, tenzij men aanneemt dat het impliciet als een verdediging was bedoeld tegen een mogelijke tegenwerking die erop neerkwam dat de SintBaafsabdij was te kort geschoten in deze belangrijke opdracht. Veelbetekenend is daarbij dat in de verdediging niet het argument wordt gebruikt dat er nog andere grondbezitters mee verantwoordelijk waren geweest. De verantwoordelijkheid van de abdij schijnt te worden erkend; alleen haar tekortkomingen moesten worden afgestreden.

Deze conclusie noopt er nu toe opnieuw het getuigenis van een bron aan te halen, waarin inderdaad verwijten betreffende schuld worden geuit aan het adres van vermeende verantwoordelijken en wel uitdrukkelijk in verband met de katastrofale gebeurtenissen van 1375.

Het gaat over een passus uit het Chronicon comitum Flandrensium ${ }^{70}$, die men evenwel wegens de talrijke onjuistheden over de stormvloed van 1375 afgewezen heeft ${ }^{71}$. De kritiek op het Chronicon is gerechtvaardigd en geldt nog steeds in zover het gaat over de datering, over de vraag of het wel degelijk over 15 dorpen ging - waarbij men evenwel niet uit het $00 \mathrm{~g}$ had mogen verliezen, dat de tekst zelf het voorzichtig heeft over "ongeveer" vijftien parochies ("fere quindecim parochiae") - en tenslotte ook over de vraag of dit cijfer niet is genoemd vanuit het standpunt dat men daarover innam in 1404, zodat ook woonplaatsen zijn bedoeld die niet volledig zijn weggespoeld. Dit alles staat nochtans losvan de volgende passus: "en dit gebeurde door de gierigheid van diegenen die het gat te Biervliet hadden moeten afdammen. $\mathrm{Zij}$ wachtten echter hiermee omdat ze intussen nog steeds dijkgeld inden. En zo brak de zee onverwacht in de voomoemde parochies binnen vanuit het punt waar een toegang voor de hand lag" ("et hoc accidit propter avaritiam illorum qui debebant obstruere het gat te Biervliet et tardaverunt eo quod semper reciperent summas vulgariter dykghelt et sic inopinate mare ex quo sibi patuit ibidem aditus intravit parochias praedictas $\left.^{\prime \prime}\right)$. Dit is een zelfstandige overlevering die niets te maken heeft met een oordeel over de aangehaalde punten van twijfel. Het inhoudelijk verband met het verslag van de getuige is bovendien duidelijk. Vele details kunnen zelfs uit de tekst worden gehaald die de tot nu toe bereikte inzichten op bevredigende wijze kunnen vervolledigen. Zo kan men al uit de in de Latijnse tekst bewaarde benaming uit de volkstaal "het gat te Biervliet" - die niet zoals in de verklaring van de getuige verlatijnst werd - nogmaals de bevestiging afleiden van onze conclusie dat niet eerst de waterloop zo heette, maar wel de op dat ogenblik al doorbroken terreinverhoging. Van die

70 Blz. 234 (ed. J.J. de Smet, Brussel, 1837).

71 Gottschalk, Stormvloeden en rivieroverstromingen 1, 1971, 431. 


\section{H. D. MEYER}

verhoging kon men zeggen dat ze door beschermingswerken had moeten afgesloten worden. Daarbij moet er ook op worden gelet, hoe een voorafgaande passus die twee elementen uit elkaar houdt wanneer hij zegt de dijken "dici" (hoewel het misschien beter was het woord "aggeres" zoals dit in een ander manuskript voorkomt, de voorkeur te geven) bij de zee en het hoofd ("promontoria") van Biervliet zijn doorgebroken wegens de te sterke stroming van de zee" ("fracti sunt propter nimium fluxum maris"). "Aggeres" zijn de aangelegde beveiligingswerken; "promontoria" de hogere gronden bij de zee, die nog vóór het uitgegraven veen liggen. Hieruit blijkt alleszins een degelijke kennis van het gebied.

Het verwijt aan hen die verantwoordelijk worden geacht is dus: zij hadden steeds dijkbelasting geincasseerd, maar de uitvoering van de dijkwerken zou te laat gebeurd zijn, uit hebzucht. Hierdoor was de doorbraak van de zee dan ook onverwachts gekomen voor de bevolking. De nadruk in het verslag van de getuige nu schijnt gericht te zijn op het verwijt van hebzucht, wanneer hij verklaart dat de abdij, verre van hebzuchtig te zijn, onder abt Johannes zelf aanzienlijke middelen ter beveiliging van het gat van Biervliet heeft ingezet, en verloren. Uit twee van elkaar onafhankelijke bronnen hebben we bijgevolg kunnen opmaken dat na de ramp van 1375 tegen Sint-Baafs alleen of ook tegen anderen het verwijt werd gemaakt dat zij mede verantwoordelijk waren voor de gebeurtenissen. Hoe twijfelachtig de kern van deze verwijten ook moge geweest zijn, zoveel staat vast dat daarbij als bekend werd aangenomen dat de beveiliging van het Gat van Biervliet een opdracht was die reeds tientallen jaren vóór de katastrofe bekend en ook metterdaad was uitgevoerd 72 .

Alle getuigen die het erover hebben, laten uitschijnen dat in het raam van de verwoestingen die tot in de verre omgeving van Biervliet hadden plaatsgevonden, het verlies van het hof van Wevelswale met alle afhankelijkheden, voor Sint-Baafs het zwaarst was. Getuige 2 noemt dit hof ${ }^{73}$ zoals hij het vaak van ingewijden heeft gehoord, één van de rijkste en vruchtbaarste bezittingen van de abdij ("una de locupletioribus et fructuosioribus possessionibus que dictum monasterium habebat"). Getuige 3 zegt bijna woordelijk hetzelfde en voegt er nog een liefelijke beschrijving van het aangename uitzicht van het domein aan toe ("quandam possessionem valde locupletam nuncupatam vulgariter Wevelswale magnam ...et latam magnisque necnon pulcris et honestis et sumptuosis edificiis decoratam") ${ }^{74}$.

72 Ingaan op verdere problemen die uit de kroniekliteratuur opduiken, zou ons al te ver voeren. Zo zou onder andere hier moeten worden verduidelijkt, wat Van Lokeren (Histoire de l'abbaye de St.Bavon 133) daarvan heeft gemaakt, en wat er eigenlijk met de sluizen van Biervliet aan de hand is geweest.

73 Fol. 5 r.

74 Fol. 6v, over de gebouwen te Wevelswale zijn we tot in biezonderheden 


\section{NIEUWE GETUIGENISSEN OVER STORMVLOEDSCHADE IN Z-V}

In de nabijheid van de stad Biervliet viel, volgens de getuigen, de schade voor Sint-Baafs wat gunstiger uit. Weliswaar is ook dáár het grootste deel van het land overstroomd ("maior pars terrarum circa villam de Biervliet iacentium") ${ }^{75}$, maar we horen ook over bezittingen van de abdij in de naaste omgeving van de stad die gespaard bleven ("terre dicti monasterii que post predictam submersionem ei remanserunt maxime in partibus circa villam de Biervliet...") ${ }^{76}$. Doch ook dáár luidt opnieuw de bekende klacht dat de opbrengst van één jaar vaak niet eens volstaat om de kosten voor de beveiliging tegen wateroverlast te dekken. Getuige 3 die dit beweert, is als afgevaardigde voor de aanleg en bescherming van de dijk in de Vier ambachten ("in dictis Quatuor Officiis deputatus pro huiusmodi terris dicandis et conservandis") daarvan heel precies op de hoogte. Hijzelf heeft tijdens zijn ambtstermijn in opdracht van de Sint-Baafsabdij, het aanzienlijke bedrag van 600 goudkronen daar uitgegeven. Hij voegt er jammer genoeg niet bij over hoeveel jaren deze som gespreid was. Het resultaat van die investering houdt hij voor twijfelachtig tot zelfs negatief. Hij gelooft ook niet dat het klooster die bestendige hoge uitgaven zal kunnen volhouden, maar verwacht integendeel binnenkort de overstroming van de landerijen in kwestie.

Behalve Wevelswale worden nog enkele parochies in de ruime omgeving van Biervliet met naam genoemd. Daarvan zijn Sint-Baafs te Oostburg en Sint-Margriete bij Oostburg al vermeld bij de behandeling van het Ambacht Oostburg. Blijven dus nog te vermelden: "St Laurentii ten Hamer", door getuigen 3 en 4 genoemd ${ }^{77}$, evenals Coudekerke, dat alleen door getuige 3 wordt vermeld. De formulering "vooral in volgende parochies" ("presertim in parochiis..."), die de opsomming inleidt, wijst erop dat deze het ergst waren getroffen. Gelet op de bronnensituatie mogen we hier voor één keer het argument "ex silentio" hanteren. Het is inderdaad veelbetekenend dat Boterzande niet tot de met name genoemde nederzettingen behoort. Zelfs als we er rekening mee houden dat het tot de zo dadelijk te vermelden "vergeten" oorden zou kunnen behoren, wordt hierdoor alleszins toch bevestigd dat het niet tot de zwaarst getroffen gemeenten behoort, dit wil zeggen, tot degene waar de abdij de grootste verliezen had geleden. Getuige 3 hecht eraan de nadruk erop te leggen dat hij nog een hele reeks plaatsen kent waar Sint-Baafs eveneens erge schade heeft geleden aan tienden en grond. Hun namen vallen hem echter nu niet in ("licet...ea omnia particula(ri)ter propter lapsum temporis nunc sibi non occurrant"), maar

ingelicht: vgl. Gottschalk, Vier Ambachten 305 vgl.

75 Fol. 8v.

76 Fol. 7r.

77 Fol. 6v., 9r. In verband deze twee stellen zich problemen inzake bronnen, die nog moeten worden opgeklaard. 


\section{H. D. MEYER}

vroeger kende hij ze alle precies ("nominatim specificanda bene novit"). Dit geheugenverlies van getuige heeft ons de mogelijkheid ontnomen, ophelderingen van een tijdgenoot er bij te halen om de kwestie van de omineuze lijst van 15 of 17 verloren gegane parochies op te helderen.

Tot slot willen wij nog enkele korte opmerkingen maken bij een dokument uit die tijd dat naar ons weten tot nog toe aan de aandacht is ontsnapt. Kort na de katastrofe van oktober 1375 moet Sint-Baafs aan de bisschop van Doornik de toestemming gevraagd hebben om door middel van lijfrenten kapitaal bijeen te brengen om vloedschade te kunnen herstellen. Op 22 juni $1376^{78}$ heeft bisschop Filip inderdaad die toestemming verleend tot de som van $30 \mathrm{lb}$. groten tournois jaarlijkse rente ("...usque ad summam triginta librarum grossorum Turonensium dicte monete annui redditus..."). Hierbij wordt de nadruk erop gelegd, dat die som niet mag worden overschreden, en enkel mag worden aangewend voor het herstellen van dijken en gebouwen ("...in refectione et reparatione dictorum dicorum et edificiorum"). In deze oorkonde treft men bovendien een interessante lijst van plaatsen waar de beschadigde bezittingen van de abdij lagen. Tegelijk vernemen we de omvang van de vroegere inkomsten uit die eigendommen waarop het verzoek doelde: "...videlicet in Cadzand, in Wulpen, in den Wert, in Moermans poel, ac in territorio de Boukhaute, Ossenesse et Moerseke" waaruit de abdij jaarlijks negenduizend pond parisis ontving en meer ("de quibus annuatim novem mille libras parisis monete Flandrie et ultra prefati abbas et conventus recipere consueverunt..."). Al deze opgesomde schadeposten zijn derhalve beslist op 1375 te dateren. Wat Cadzand, Wulpen en Weert aangaat, wordt hier bevestigd wat eerder al gezegd werd: zij behoren tot de sterk getroffen bezittingen, die zeer snel hulp nodig hebben. Vooral hetgeen hoger betreffende de financiering van de herstellingen te Weert werd geconcludeerd, wordt door deze oorkonde gestaafd: de abdij neemt kapitaal op. Evenzo wordt de schade te Ossenisse bevestigd, die we hoger voor het eerst in 1375 hebben kunnen aantonen. Anders dan de getuigen uit 1412 en ook meer precies dan zij, spreekt de oorkonde niet gewoon over de verwoestingen bij (Oud) Otene, maar ze vernoemt zelfs de aldaar gelegen Moermanspolder bij name ${ }^{79}$, hoewel in de ongewone vorm "Moermans poel". Dat Sint-Baafs niet ver van Weert, in Moerzeke, ingedijkt land bezat, vernemen we eveneens uit de tekst.

De lijst heeft uiteraard geen enkel representatief karakter of waarde wat de schade betreft die in 1375 in deze streek voor de Sint-Baafsabdij is ontstaan. De abdij heeft hem samengesteld met het klaarblijkelijke doel tot de vermelde som van $9000 \mathrm{lb}$. par. te komen. De berekening van de omvang van

79. Vgl. K2308 fol. 11 en Gottschalk, Vier Ambachten 371. 


\section{NIEUWE GETUIGENISSEN OVER STORMVLOEDSCHADE IN Z-V}

de lening verwees dan ook op een uitgekiende manier naar die som. De houding van de bisschop die de lening heeft toegezegd, is duidelijk restriktief: slechts $3 \%$ ongeveer van de vroegere inkomsten - die men toch met de investeringen opnieuw wil bereiken - wordt als jaarlijkse aflossingssom toegestaan. Neemt men nu als waarschijnlijke rentevoet $10 \%$, dan kon Sint-Baafs onder deze voorwaarden zowat 225 lb.gr. aan kapitaal opnemen. Dat is minder dan één derde van de vroegere opbrengst per jaar.

Met deze opmerkingen kan de interpretatie van de inhoud van de nieuwe getuigenissen afgerond worden. Hierdoor werd inzicht verkregen in de bilans van de schade, die de Sint-Baafsabdij in de bewogen veertig jaren sedert 1375 heeft moeten opmaken voor haar bezittingen in de vijf onderzochte streken, met name de Ambachten Aardenburg, Oostburg en Ijsendijke; de Vier Ambachten; Cadzand-Wulpen; Weert en Altena, evenals de omgeving van Biervliet.

Hoever kunnen we nu vertrouwen hebben in de verkregen inlichtingen ? We behoeven de kompetentie van de getuigen niet andermaal te behandelen. Evenmin gaan we in op vragen die samenhangen met de typische gebreken van literaire overlevering, in het bijzonder van kronieken. We willen het enkel hebben over de zorgvuldigheid en het streven naar waarheid bij de getuigen. Deze hebben nooit aanleiding tot twijfel gegeven. Ze gaven integendeel voortdurend blijk van grote ernst. Deze kwaliteiten werden uiteraard versterkt door het feit dat de inlichtingen van de betrokkenen in een formele aangelegenheid onder eed werden gegeven en later in een verslag werden vastgelegd. Anderzijds is het verhoor ook weer niet helemaal naar recht en wet geschied, dit wil zeggen, dat hetgeen de ene getuige beweerde door de andere mocht worden betwist en dat zij elkaar mochten tegenspreken. Vandaar ook dat we op sommige plaatsen rekening moeten houden met lichte overdrijvingen, met sterke aksenten en zelfs met ongerechtvaardigde veralgemeningen. $\mathrm{Er}$ is desondanks geen enkele aanwijzing dat ergens een valse verklaring zou afgelegd zijn. Ook vinden we geen sporen van verkeerde loyauteit tegenover de abdij. Er moet trouwens op worden gewezen, dat integendeel getuigen vaak weigeren de hun voorgelegde toedracht van een zaak zó maar te aanvaarden of ze in ieder geval in de hun voorgelegde vorm aan te nemen, als ze van mening zijn, dat een en ander niet strookt met hun opvatting van de waarheid. Hierbij komt nog dat met de verklaringen van onze getuigen lang niet alles ten gronde was behandeld, zodat men, indien men er waarde aan had gehecht, nog een hele reeks feiten had kunnen aanhalen. Maar dat heeft men nu eenmaal niet gedaan.

Wel verdient in dit verband het volgende nog een korte behandeling, met name het opvallend vaak en erg onbevangen voorkomende begrip "irrecuperabiliter" ("onherroepelijk") bij de beoordeling van landverliezen door overstroming. De abdij zelf had die uitdrukking al gebruikt in de eerste 


\section{H. D. MEYER}

zin van haar brief aan de diocesane commissaris Van Eyk. Daarin komt ze zelfs tot tweemaal toe voor ("Primo quod valiores et fructuosiores decime predicti monasterii cum multis terris pratis pascuis et aliis possessionibus suis per diversas inflationes et tempestuosas inundationes tam maris quam aquarum fluvialium a XL annis citra irrecuperabiliter submerse sunt et ubi solebat esse arida ibi nunc est magnum mare per quam submersionem predictum monasterium quasi medietatem possessionum et redditum irrecuperabiliter amisit"). Natuurlijk kan dit hier niet bedoeld zijn in de absolute zin van "op geen enkelijke manier ooit weer terug te winnen". Zo iets zou dan wel de opwerping hebben uitgelokt van hoe men dat zo precies kon weten. Getuige 3, Boudewijn Utenhove (Balduinus de Curia), is zich daarvan bewust, want hij wendt het woord niet zo maar aan, doch met een beperkend zinnetje, als hij van het hof van Wevelswale en haar omgeving zegt: "...que nunc...omnino et ut permittitur irrecuperabiliter est submersa". Blijft dus de vraag waarom men dan toch die uitdrukking heeft gebruikt. Waarom was het niet voldoende eenvoudig de verliezen te beschrijven, zonder de mogelijkheid van terugwinning te vermelden? Dit kunnen we alleen maar leren uit de toepassingen van die uitdrukking.

Daartoe mag echter het geval Wevelswale niet als voorbeeld worden genomen, aangezien juist hier, bij wijze van uitzondering, de absolute betekenis van "onherroepelijk verloren" voor de hand lag, hetgeen in $1412 \mathrm{al}$ erg duidelijk moest zijn. Alle andere gevallen tonen klaar en duidelijk aan, hoe de stilzwijgende beperking van het woord dient te worden verstaan. Getuige 1 zegt "dat het grootste deel van het Brugse Vrije (volgen dan de drie westelijke Ambachten en Cadzand-Wulpen) en een groot deel van de andere Vier Ambachten van Vlaanderen, achtereenvolgens en onherroepelijk overstroomd waren ("maior pars Franci territorii Flandrie ac etiam magna pars Quatuor aliorum officiorum Flandrie...successive fuerunt et irrecuperabiliter sunt submerse") ${ }^{80}$. Uiteraard kan aan deze globale aanduiding van het gebied niet de absolute betekenis worden toegekend in de zin dat daarvan "geen stuk grond ooit meer zou kunnen teruggewonnen worden". Hetzelfde geldt voor wat getuige 10 over het Ambacht Ijsendijke zegt ("...cum officium ipsum totaliter sit...manifestum est remaneat irrecuperabiliter submersum") ${ }^{81}$. Of nog voor hetgeen de algemeen ontvanger (getuige 15) ${ }^{82}$ over alle bezittingen van Sint-Baafs in het gehele Brugse Vrije zegt ("...irrecuperabiliter perdidit et amisit").

Men kan dus niets anders dan te aanvaarden dat die uitdrukking slechts een beperkte betekenis had. Bedoeld werd dat de terugwinning van het verloren gebied weliswaar niet onmogelijk was, maar dat ze wel moeilijk zou zijn en

$\begin{array}{ll}80 & \text { Fol. 2v. } \\ 81 & \text { Fol. 14v. } \\ 82 & \text { Fol. 18v. }\end{array}$




\section{NIEUWE GETUIGENISSEN OVER STORMVIOEDSCHADE IN Z-V}

zeer duur. Als men rekening houdt met het feit, dat verwoestingen van een zekere omvang in die tijd heel gewoon waren en zeer dikwijls voorkwamen, dan komt men tenslotte tot een nagenoeg technische betekenis van het begrip "irrecuperabiliter submersum", ongeveer te vertalen als: "niet met normale opruimingswerken en herstellingen opnieuw produktief te maken". Dit gold dan wel voor alle landerijen waarop het water verwoestingen had aangericht die te vergelijken zijn met die van het Gat van Biervliet. In positieve zin bedoelen de getuigen dat "enkel door een totaal nieuwe indijking, met de volle kosten vandien, het land kon worden teruggewonnen". Zo wordt het begrijpelijk, dat de door de rampen getroffen bezitters er groot belang aan hechtten dergelijk overstroomd land niet maar gewoon als 'overstroomd' aan te duiden, maar het bovendien op deze manier te beschrijven. Zeer duidelijk blijkt dit uit de verklaring van getuige 9 als hij zegt, over de in 1404 overstroomde bezittingen in ljzendijke, die in 1375 niet getroffen waren, "dat ze werden overstroomd en het nog steeds zijn en dat ze onherroepelijk overstroomd blijven" ("...submergebantur et adhuc sunt et remanent irrecuperabiliter submerse"). Dit gebied wil hij natuurlijk niet als voor eeuwig verloren bestempelen. Zijn woorden betekenen: "het land werd ooit overstroomd (in 1404) en staat nù (in 1412) nog steeds onder water; en zó zal het ook blijven als het niet totaal opnieuw wordt ingedijkt". 


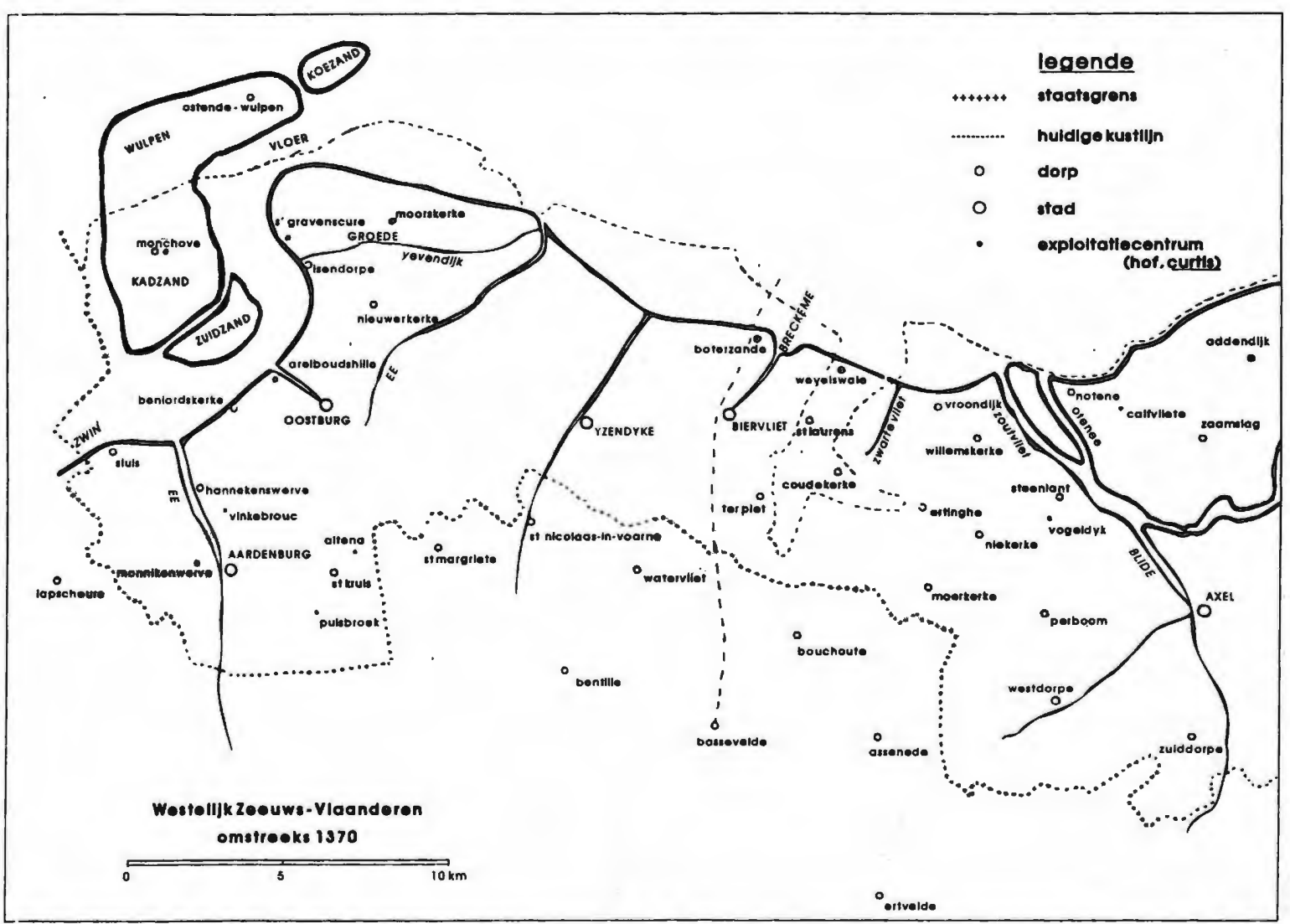

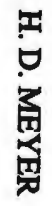

